\title{
Factors Influencing the Bacterial Bioremediation of Hydrocarbon Contaminants in the Soil: Mechanisms and Impacts
}

\author{
Gessesse Kebede $\mathbb{C D}^{1,2}$ Tekle Tafese $\mathbb{C}^{1},{ }^{1}$ Ebrahim M. Abda $\mathbb{D}^{1,2}$ M. Kamaraj ${ }^{10},{ }^{1,2}$ \\ and Fassil Assefa ${ }^{3}$ \\ ${ }^{1}$ Department of Biotechnology, College of Biological and Chemical Engineering, Addis Ababa Science and Technology University, \\ Addis Ababa 16417, Ethiopia \\ ${ }^{2}$ Bioprocess and Biotechnology Center of Excellence, Addis Ababa Science and Technology University, \\ Addis Ababa 16417, Ethiopia \\ ${ }^{3}$ Department of Cellular Microbial and Molecular Biology, Addis Ababa University, Addis Ababa 1176, Ethiopia
}

Correspondence should be addressed to M. Kamaraj; drkamarajm@gmail.com

Received 29 July 2021; Revised 26 September 2021; Accepted 27 October 2021; Published 15 November 2021

Academic Editor: Yuhe He

Copyright () 2021 Gessesse Kebede et al. This is an open access article distributed under the Creative Commons Attribution License, which permits unrestricted use, distribution, and reproduction in any medium, provided the original work is properly cited.

\begin{abstract}
The discharge of hydrocarbons and their derivatives to environments due to human and/or natural activities cause environmental pollution (soil, water, and air) and affect the natural functioning of an ecosystem. To minimize or eradicate environmental pollution by hydrocarbon contaminants, studies showed strategies including physical, chemical, and biological approaches. Among those strategies, the use of biological techniques (especially bacterial biodegradation) is critically important to remove hydrocarbon contaminants. The current review discusses the insights of major factors that enhance or hinder the bacterial bioremediation of hydrocarbon contaminants (aliphatic, aromatic, and polyaromatic hydrocarbons) in the soil. The key factors limiting the overall hydrocarbon biodegradation are generally categorized as biotic factors and abiotic factors. Among various environmental factors, temperature range from 30 to $40^{\circ} \mathrm{C}, \mathrm{pH}$ range from 5 to 8 , moisture availability range from 30 to $90 \%$, carbon/nitrogen/phosphorous (C/N/P; 100:20:1) ratio, and 10-40\% of oxygen for aerobic degradation are the key factors that show positive correlation for greatest hydrocarbon biodegradation rate by altering the activities of the microbial and degradative enzymes in soil. In addition, the formation of biofilm and production of biosurfactants in hydrocarbon-polluted soil environments increase microbial adaptation to low bioavailability of hydrophobic compounds, and genes that encode for hydrocarbon degradative enzymes are critical for the potential of microbes to bioremediate soils contaminated with hydrocarbon pollutants. Therefore, this review works on the identification of factors for effective hydrocarbon biodegradation, understanding, and optimization of those factors that are essential and critical.
\end{abstract}

\section{Introduction}

The demand and utilization of petroleum-derived hydrocarbon products lead to the contamination of environments such as air, water, and soil. Unfortunately, the releasing of hydrocarbon contaminants into the soil naturally or anthropologically affects both biotic and abiotic components of ecosystems [1]. To overcome pollutions caused by various hydrocarbon-derived pollutants, many researchers have been showing that physical, chemical, and biological methods are routinely used for the treatment of contaminated sites $[2,3]$. Moreover, biological remediation is a cost-effective, simple, efficient, noninvasive, apply in situ, ecologically friendly, sustainable, and applicable approach [4-7]. The bioremediation technique comprises phytoremediation (rhizodegradation, phytoextraction, phytovolatilization, phytodegradation, rhizofiltration, and rhizostabilization), mycoremediation, microbial remediation, and phycoremediation. Studies specified that microbial bioremediation (the use of microorganisms: bacteria, fungi, and microalgae) is the most efficient to transform pollutants into less toxic and less mobile form or to mineralize 
hydrocarbon contaminants into $\mathrm{H}_{2} \mathrm{O}, \mathrm{CO}_{2}$, and microbial biomass $[8,9]$. Among various microorganisms, bacteria are the most active and the primary hydrocarbon degraders [10]. Microorganisms that can survive and proliferate on hydrocarbon pollutants as their sole source of carbon and energy have evolved due to the introduction of hydrocarbon pollutants into the environment. Increased metabolic capacities could be gained through horizontal/vertical gene transfer and mutations, thereby acquiring genes whose products are involved in the breakdown of hydrocarbons. Even though such microbes have the potential to degrade hydrocarbon contaminants, certain limiting factors (biotic and abiotic) impinge on the efficient biodegradation of contaminants [11, 12]. Hydrocarbon and its associated environmental problems are received much attention in recent years worldwide. Consequently, there is noteworthy attention to degrade or eliminate pollutants using the natural population of microbes (bacteria, fungi, and microalgae) to have a pollution-free environment. For this, several studies have reported the impacts of various hydrocarbon and diverse remediation techniques. Based on historical publications, bibliometric analysis is a popular and successful tool for determining research trends and relevant concerns. It has been employed in a variety of scientific and engineering fields [13]. The keywords are provided in the Scopus database as follows: "TITLE-ABS-KEY (\{bioremediation\} AND \{hydrocarbon\} AND \{soil\} AND \{factors\}," to find the critical evaluation of the articles that discussed major optimization factors in bioremediation of hydrocarbons in soil from 2012-2022. The database showed 417 articles, and their year-wise publication is depicted in Figure 1(a). The country-wise search showed that the United States held the major number of publications (Figure 2(b)), and the type of document search revealed that a high number of publications are published under the article category (Figure 1(c)). The major three subject areas covered in the query is falling under environment science, immunology and microbiology, and agricultural and biological science (Figure 1(d)). The numerical values of articles based on the provided keywords in the reputed database collection such as "Scopus" indicate the continuous research development in the concerned field, which highly promotes further research and review. The application of bioremediation technology is not supreme, and it is affected by numerous factors that hamper its practical application, limiting the large-scale application of the techniques for hydrocarbon biodegradation practices. Accordingly, bacterial bioremediation of hydrocarbons in various environmental systems has received all-inclusive interest, and a systematic review is most needed to highlight the factors affecting the rate of bacterial bioremediation. Hence, the current review is designed to elucidate the key factors that influence the bacterial bioremediation of hydrocarbon in soil with their impacts.

\section{Hydrocarbon Contaminations and Their Sources}

Hydrocarbons are naturally occurring compounds that are principally formed from plant and animal fossils due to natural or anthropogenic actions. They are made up entirely of carbon and hydrogen atoms and serve as the foundation for crude oil, natural gas, and coal, providing a significant proportion of the world's energy. Hydrocarbons are classified as saturates (branched and straight-chained), aromatic (mono and polycyclic), resins (pyridines, quinolines, carbazoles, sulfoxides, and amides), and asphaltenes (phenols, fatty acids, ketones, esters, and porphyrins) $[8,14,15]$. Hydrocarbons and their derivatives were intentionally or accidentally discharged into the environment, mainly to the soil and oceans, and principally existed in three physical states, that is, solid, liquid, or gaseous [16]. The major sources of contamination are human activities (anthropogenic) and natural processes. The anthropogenic activities are related to the current increase in industrialization and civilization and generally contribute to the increased accumulation of hydrocarbon contaminants in the environment. Thus, sources include garages, gas station services, mining, wastes from chemical and petrochemical industries, agriculture wastes, incomplete combustion of organic matter, sludge wastes, gasification, automobile exhaust and processing, production, transportation, run-off asphalt pavements, volcanic eruption, the distillation of wood, waste disposals, vehicular emission, and combustion of fossil fuel $[14,17,18]$. Thereby, most hydrocarbon-contaminated environments contain light petroleum products (oil, gasoline, kerosene, and diesel), heavy hydrocarbons (environments lubricants, heavy oil, and crude oil), halogenated solvents, and other more complex molecules (aromatic hydrocarbons) [1,11]. The difficulty of cleaning up of environment contaminated with hydrocarbon pollutants is the ability to identify potential sources either point or nonpoint sources. Consequently, differentiating and identifying of origin of hydrocarbon contaminants help apply imperative bioremediation techniques.

\section{Environmental and Health Impact of Hydrocarbon Contamination}

Pollution from hydrocarbon is a worldwide exemplar that raises animal, environmental, and human health concerns. Recently, the potential of hydrocarbon contaminants has received increasing attention of particular concern on the aquatic, marine, and land environment. Studies have been indicated that hydrocarbon can have a significant adverse impact on ecosystems [19]. Thereby, hydrocarbon contamination leads to the deterioration of the ecosystem's functioning and its living (fauna) and nonliving components [20]. In addition, when hydrocarbons are introduced into the soil, they can hamper the supply of water, nutrients, oxygen, light, and other parameters for the biological processes. This can affect soil fertility (plant growth and seed germination) and consequently agricultural productivity $[17,21]$. Hydrocarbon contaminants cause immediate or latent effects such as genetic mutations, immunotoxicity, teratogenicity, carcinogenesis, high bioaccumulation potential, and deterioration of the ecosystem functioning and treating of animal and plant life $[1,14,22-26]$. The xenobiotic form of hydrocarbons can also sorb to organic-rich soils and sediments, accumulate in organisms (fish, plants, and other aquatic organisms), and may be transferred to the 


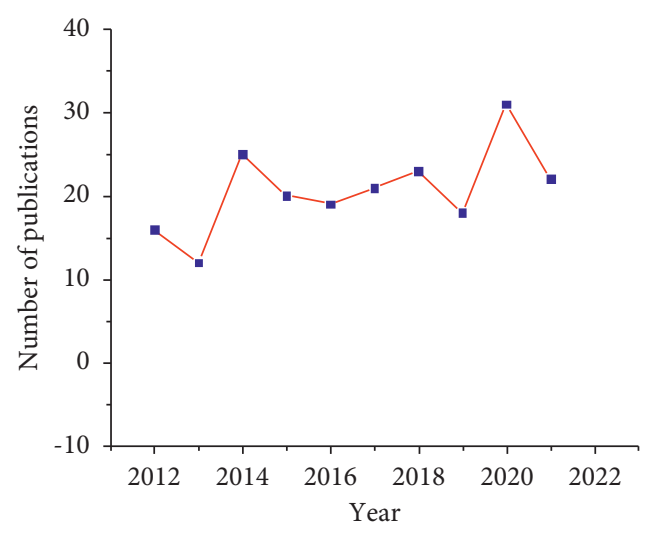

(a)

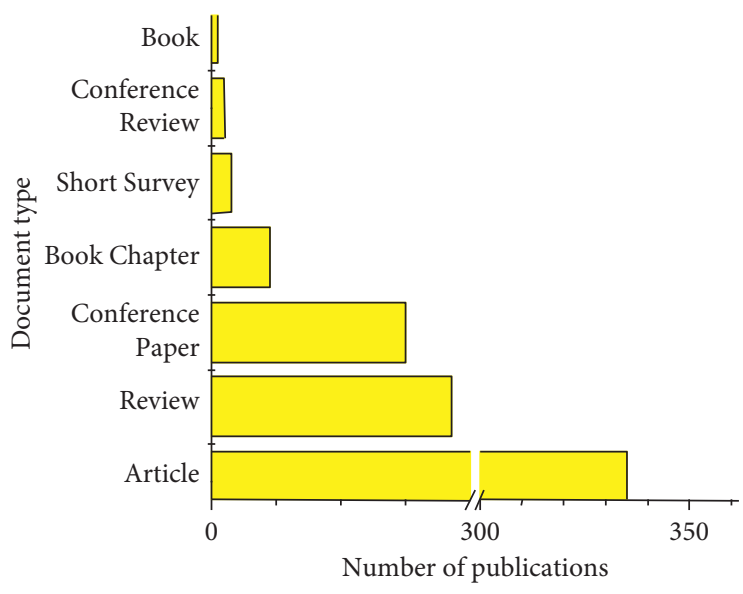

(c)

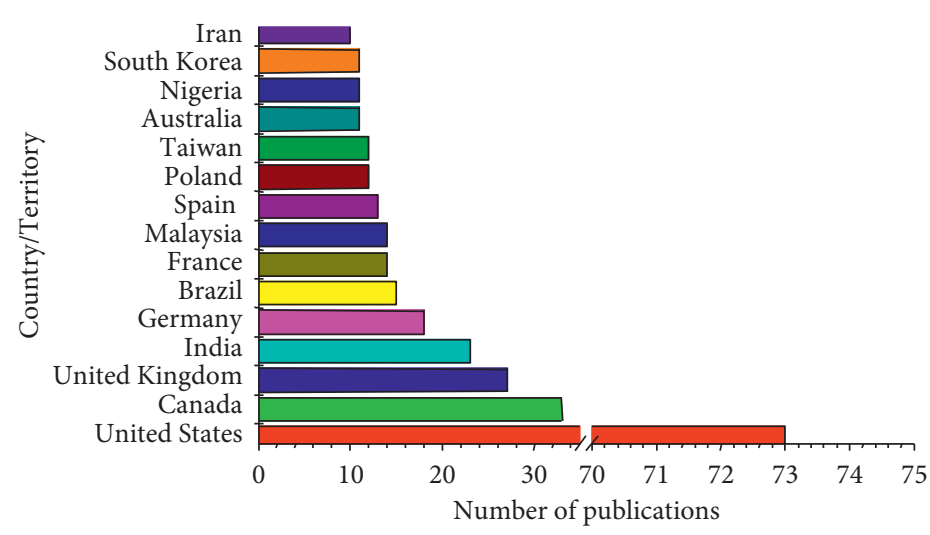

(b)

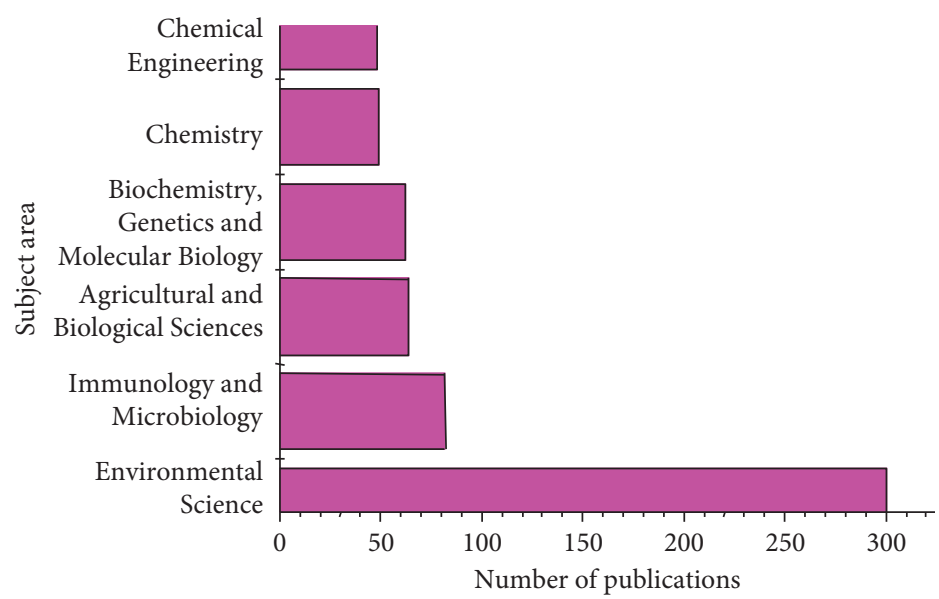

(d)

FIGURE 1: Graphical representation for the scopus database document output for the keywords (TITLE-ABS-KEY (\{bioremediation\} AND \{hydrocarbon\} AND \{soil\} AND \{factors\}) (Scopus database as on 16 July 2021): (a) documents for year-wise for the period of 2012-2021, (b) documents by major fifteen countries/territories, (c) documents by type, and (d) documents by major six subject areas.

food chain and badly disturb the exposed organisms [17]. The bioaccumulation and biomagnification of hydrocarbons also cause defects in the reproductive, immune system, neurologic, and developmental stages (teratogenic) and also cause cancers of the skin, lung, bladder, liver, and gastrointestinal $[9,23]$. Therefore, exposure to hydrocarbon contaminants causes several health impacts. In addition, the hydrocarbon contamination and its toxicity diminish species richness, evenness, and phylogenetic variety, with the resulting community in a contaminated soil environment [27]. Therefore, hydrocarbon contaminants in the environment are known to cause significant impairment to the environment and organisms. Due to this and other complex problems with contamination of hydrocarbon components, microorganisms are isolated and screened as environmental remediation agents for increasing the rate of removal of the contaminants to make a healthy environment.

\section{Hydrocarbon Bioremediation in the Soil}

Bioremediation refers to the removal, destruction, immobilization, mineralization, or transformation of contaminants from the soil with the use of plants, protozoa, fungi, and microalgae [28, 29] and particularly bacteria [3] and their products in the presence of optimal conditions. Bioremediation methods with low operational costs for the removal or reduction of inorganic and organic pollutants (hydrocarbons, halogenated organic compounds, halogenated organic solvent, nonchlorinated pesticides and herbicides, nitrogen compounds, and heavy metals (lead, mercury, chromium, radionuclide, etc.) at least to the level that they cannot cause a serious effect to ecological functions $[29,30]$. For such application, various macro- and microorganisms are used, but bacteria are selectively useful to degrade a variety of hydrocarbon pollutants and are ubiquitous $[29,31]$ and applied for in situ or ex situ bioremediation processes. In situ bioremediation refers to treating contaminants at the site with minimal disturbance using methods such as bioventing, biostimulation, bioaugmentation, and/or natural attenuation [32], while ex situ refers to the destruction or treatment of the contaminant from the site by using methods such as excavation, landfilling, composting, incineration, biopiles, and bioreactors [33]. In general, the different methods of bioremediation mechanisms are broadly categorized into natural attenuation, bioaugmentation, and biostimulation [20] (Figure 2 and Table 1). 


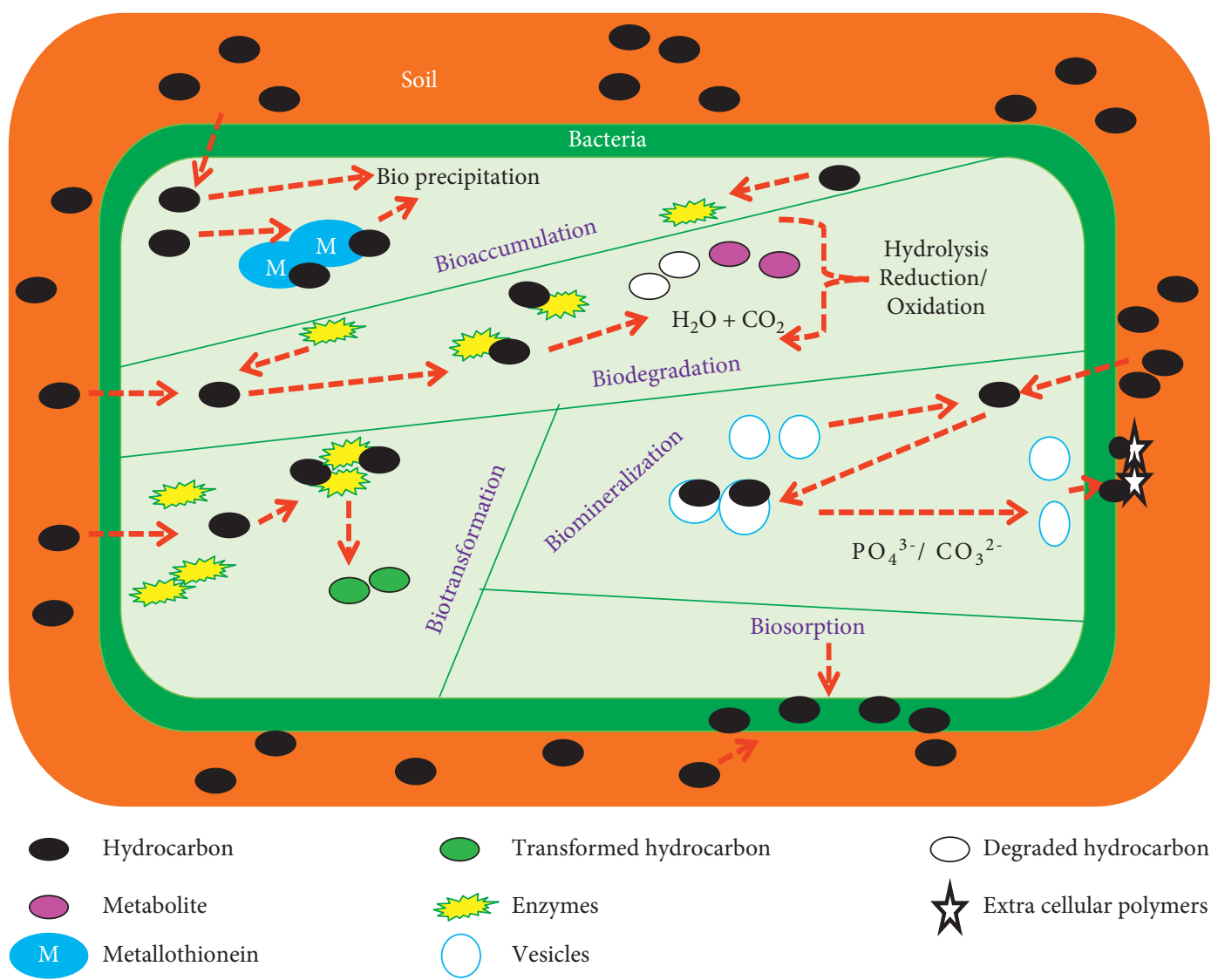

Figure 2: The mechanisms of microbial remediation used for reducing heavy metals [34].

\subsection{Natural Attenuation/Intrinsic Bioremediation.} Natural attenuation (natural remediation) refers to the use of indigenous microbial populations to eliminate or detoxify hazardous hydrocarbon pollutants into less or nontoxic forms [47]. The time required essential for natural attenuation depends on contamination, site conditions, and applicability of potential degrading bacteria. This implies that the use of natural attenuation is cost-effective and efficient if there is no need for a complex remediation process [47]. Thus, researches showed that this strategy is effective in degrading $25 \%$ of hydrocarbon pollutants in soil [15]. During this process, the indigenous microbes utilize hydrocarbon contaminants as the sole carbon and energy sources based on their natural metabolic pathways [48]. When the soil is contaminated with hydrocarbon contaminants, the number of indigenous hydrocarbon-degrading microorganisms increase rapidly and start to adapt to and metabolize (degrade) the pollutants. The bacterial metabolic pathways for the degradation of hydrocarbon contaminants are illustrated in Figure 3. Studies showed that natural attenuation is dependent on naturally occurring (indigenous) hydrocarbon degraders [9]. However, its effectiveness is contingent on nutrient availability, type and concentration of contaminants, physical parameters, the fate of contaminants, and potential microbial communities with necessary catabolic genes for complete hydrocarbon degradation. Albeit, natural attenuation is often a slow process, and its effectiveness can be achieved when supported with bioaugmentation and biostimulation techniques [21, 25].
4.2. Bioaugmentation. Bioaugmentation refers to the introduction of potential microbial strain or consortia isolated from other contaminated sites or the genetically modified microbes to support the remediation $[49,50]$. This strategy is usually applied when natural attenuation is ineffective due to low indigenous hydrocarbon-degrading population, sluggish decontamination activities, and high-stress situations to start the bioremediation process [10]. For successful hydrocarbon biodegradation, the inocula must be able to metabolize broad ranges contaminants, not undergo mutation, withstand various biotic and abiotic factors, and effectively compete with other microorganisms (indigenous hydrocarbon-degrading and predators) and can easily reach contaminants in deep via pores of the sediment [51]. For the bioremediation approaches, microbial cell bioaugmentation is a commonly used technique for the removal of contaminants. In addition, there are several bioaugmentation techniques: phytoaugmentation, rhizosphere bioaugmentation, gene bioaugmentation that have been exercised for cleaning up contaminated sites.

4.3. Biostimulation. Biostimulation is the addition of growth-limiting factors such as substrates, vitamins, oxygen, and modifying the environmental conditions (temperature, moisture, $\mathrm{pH}$, redox potential, terminal electron acceptors, etc.) in the hydrocarbon-contaminated environments $[49,50,52]$. This is important to improve the metabolic 
TABLE 1: Overview of strategies and mechanisms employed for bioremediation of hydrocarbon.

\begin{tabular}{|c|c|c|c|c|c|}
\hline Contaminant & Mode of test & Removal mechanism & Duration & Efficiency & Reference \\
\hline $\begin{array}{l}\text { Crude oil (TPH at } \\
20 \mathrm{~g} / \mathrm{kg})\end{array}$ & $\begin{array}{c}\text { Soil } \\
\text { microcosms }\end{array}$ & Bioaugmentation + biostimulation & 30 days & $36-51 \%$ & {$[35]$} \\
\hline $\begin{array}{l}\text { Crude oil (either } \\
20 \mathrm{~g} / \mathrm{kg} \text { or } 50 \mathrm{~g} / \mathrm{kg})\end{array}$ & $\begin{array}{l}\text { Field study in } \\
\text { soil }\end{array}$ & $\begin{array}{c}\text { Biostimulation }+ \text { surfactant-assisted } \\
\text { biodegradation }\end{array}$ & 486 days & $49-62 \%$ & [36] \\
\hline Crude oil $(20 \mathrm{~g} / \mathrm{kg})$ & $\begin{array}{l}\text { Bioreactors } \\
\text { with soil }\end{array}$ & $\begin{array}{c}\text { Natural } \\
\text { attenuation }+ \text { bioaugmentation }+ \text { biostimulation }\end{array}$ & 60 days & $51-90 \%$ & [37] \\
\hline PAHs $(574$ mg/kg) & $\begin{array}{c}\text { Soil } \\
\text { microcosms }\end{array}$ & Surfactant-assisted biodegradation & 84 days & $72-77 \%$ & [38] \\
\hline $\begin{array}{l}\text { PAHs: } \\
\text { Phenanthrene, } \\
\text { fluoranthene, and } \\
\text { pyrene }(6 \mathrm{mg} / \mathrm{kg})\end{array}$ & $\begin{array}{l}\text { Soil } \\
\text { microcosms }\end{array}$ & Surfactant-assisted biodegradation & $\begin{array}{l}\text { Up to } 35 \\
\text { days }\end{array}$ & $\begin{array}{l}72 \% \text { for phenanthrene, } \\
64 \% \text { for fluoranthene, } \\
\text { and } 58 \% \text { for pyrene at } \\
\text { day } 7\end{array}$ & {$[39]$} \\
\hline PAHs $(1.5 \mathrm{~g} / \mathrm{kg})$ & $\begin{array}{l}\text { Soil } \\
\text { mesocosms }\end{array}$ & Bioaugmentation + biostimulation & 56 days & $99 \%$ & {$[40]$} \\
\hline $\begin{array}{l}\text { Diesel oil and diesel/ } \\
\text { biodiesel blends }(1 \% \\
\text { v/w) }\end{array}$ & $\begin{array}{c}\text { Soil } \\
\text { microcosms }\end{array}$ & Bioaugmentation & $\begin{array}{c}64.5 \\
\text { weeks }\end{array}$ & $88-97 \%$ & {$[41]$} \\
\hline Pyrene $(10 \mathrm{mg} / \mathrm{kg})$ & $\begin{array}{l}\text { Soil } \\
\text { microcosms }\end{array}$ & $\begin{array}{l}\text { Bioaugmentation }+ \text { biosurfactant/surfactant- } \\
\text { assisted biodegradation }\end{array}$ & 10 days & $60 \%$ & {$[42]$} \\
\hline $\begin{array}{l}\text { Diesel oil } \\
\text { hydrocarbons }(3 \mathrm{~g} / \\
\mathrm{kg})+ \text { PAHs }(400 \mu \mathrm{g} / \\
\mathrm{kg})\end{array}$ & $\begin{array}{l}\text { Weathered } \\
\text { oily soil } \\
\text { biopiles }\end{array}$ & $\begin{array}{l}\text { Bioaugmentation }+ \text { biostimulation }+ \text { surfactant- } \\
\text { assisted biodegradation }\end{array}$ & 160 days & $\begin{array}{l}39 \% \text { for diesel oil } \\
\text { hydrocarbons and } 32 \% \\
\text { for PAHs }\end{array}$ & {$[43]$} \\
\hline Diesel oil (1\% v/v) & Flask tests & $\begin{array}{c}\text { Natural attenuation }+ \text { autochthonous } \\
\text { bioaugmentation }\end{array}$ & 7 days & $20-40 \%$ & [44] \\
\hline $\begin{array}{l}\text { Engine oil }(39-41 \mathrm{~g} / \\
\mathrm{kg} \text { TPH) }\end{array}$ & $\begin{array}{c}\text { Soil } \\
\text { microcosms }\end{array}$ & $\begin{array}{c}\text { Natural } \\
\text { attenuation }+ \text { bioaugmentation }+ \text { biostimulation }\end{array}$ & 210 days & $31-75 \%$ & {$[45]$} \\
\hline $\begin{array}{l}\text { Petroleum refinery } \\
\text { waste (TPH at } 144 \mathrm{~g} / \\
\mathrm{kg})\end{array}$ & $\begin{array}{c}\text { Vial } \\
\text { microcosms }\end{array}$ & $\begin{array}{c}\text { Natural } \\
\text { attenuation }+ \text { bioaugmentation }+ \text { biostimulation }\end{array}$ & 120 days & $57-75 \%$ & {$[46]$} \\
\hline
\end{tabular}

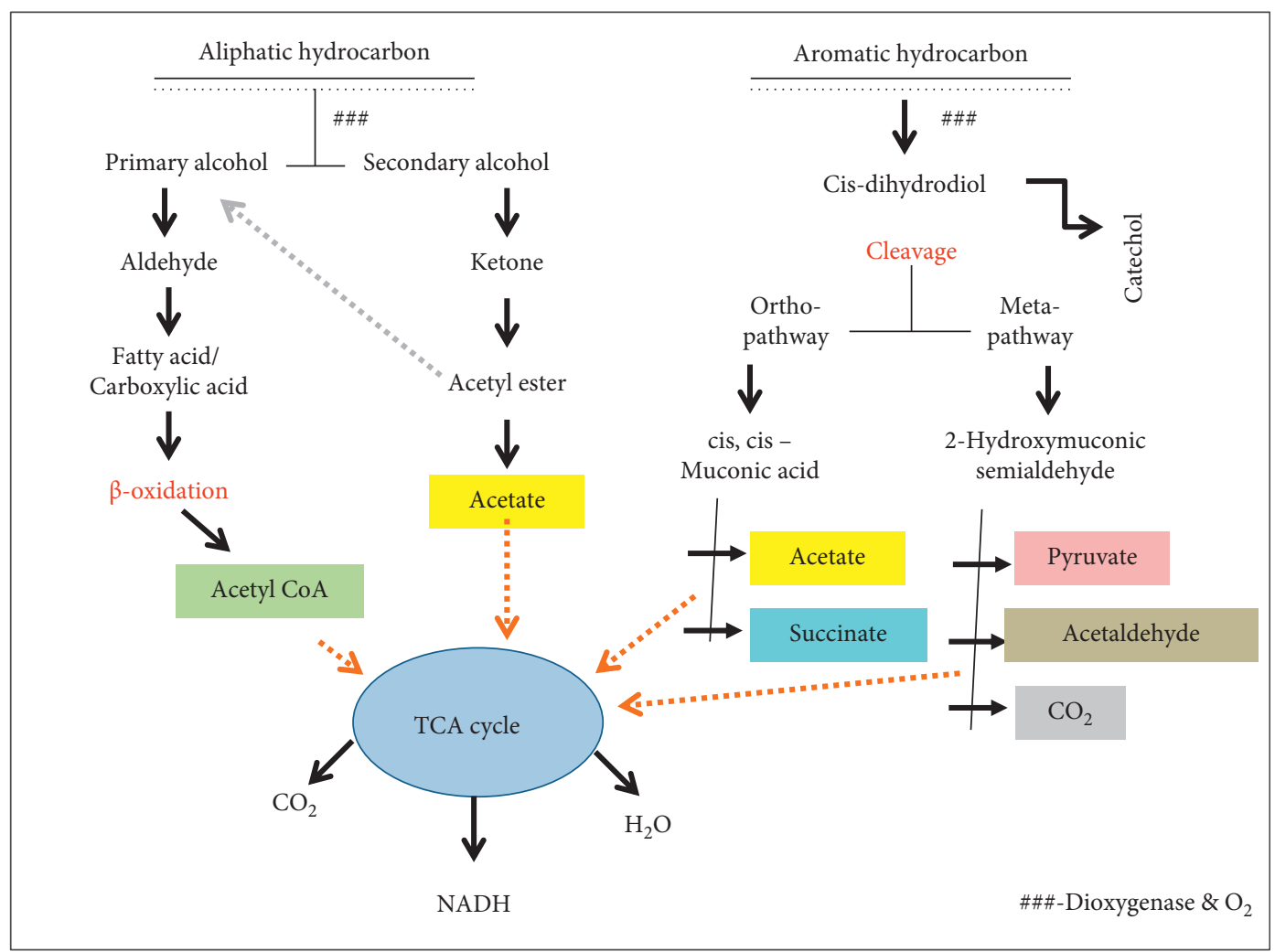

Figure 3: Bacterial metabolic pathways for the degradation of hydrocarbon contaminants [30]. 
capability of autochthonous hydrocarbon-degrading bacteria. When hydrocarbon contaminants are greatly available, they provide high carbon and energy but nitrogen or phosphorus for bacterial growth [31]. Hence, there is the need for the addition of nutrients in hydrocarbon-contaminated sites to increase the required nutrients and stimulate the growth of indigenous bacteria [52]. However, there are certain limitations for effective biostimulation application. These include the rapid depletion of major inorganic nutrients (NP), the nature of the soil, and the scarcity of indigenous hydrocarbon-degrading bacteria [53]. When indigenous or autochthonous microbial species are not fast enough to degrade pollution, microbial activity can be stimulated with the supplement of nutrients in the form of fertilizers such as $\mathrm{KNO}_{3}, \mathrm{NaNO}_{3}, \mathrm{NH}_{3} \mathrm{NO}_{3}, \mathrm{~K}_{2} \mathrm{HPO}_{4}$, and $\mathrm{MgNH}_{4} \mathrm{PO}_{4}$ [47]. Henceforward, if there are hydrocarbondegrading bacteria in the hydrocarbon polluted environments, it requires the supply of nutrients (biostimulation) and oxygen (via bioventing or biosparging), for rapid degradation of hydrocarbon contaminants [54]. Therefore, biostimulation is important to increase the efficiency of hydrocarbon-degrading bacteria. In general, the simultaneous application of bioaugmentation and biostimulation brings substantial and operative hydrocarbon bioremediation approaches by considering the major factors affecting the complete degradation of contaminants in the environment [21]. These factors are discussed below in detail.

\section{Factors Affecting Bacterial Bioremediation}

Many kinds of research have been conducted on the bioremediation of hydrocarbon-contaminated soil. Researchers have been proved that the use of a single strain or consortia of indigenous bacteria in the laboratory is effective for the biodegradation of hydrocarbon but often limited in the field [23]. This is because of the prevalence of diverse factors that affect the efficiency and rate of biodegradation. The overview of major classes of factors influencing the bacterial remediation of hydrocarbons in the soil is summarized in Figure 4. The major factors include characteristics of microorganisms (microbial consortia, metabolic potential, population density, ability to produce biosurfactant, and competition), the physicochemical properties of contaminants (chemical structure, concentration, toxicity, and bioavailability), and environmental factors (soil type, temperature, $\mathrm{pH}$, oxygen, salinity, nutrient, and water availability) $[24,33,55,56]$. Those factors alter microbial activities, degradative enzyme activities, and hydrocarbon degradation in general. This is an indication that bacterial bioremediation could be effective and enhanced if these factors are manipulation, optimized and regulated.

\section{Biotic Factors}

6.1. The Availability of Hydrocarbon-Degrading Bacteria. Hydrocarbon degrading bacteria are abundantly and ubiquitously found in hydrocarbon-contaminated soils. This is because those bacteria can easily adapt to the hydrocarbon-contaminated sites and use the contaminant as a source of carbon and energy for their metabolism and growth. The rate of hydrocarbon biodegradation is directly correlated to the availability of naturally existing potential hydrocarbon-degrading organisms in the contaminated environment [57]. Those potential bacteria are metabolically active and can degrade hydrocarbon contaminants aerobically or anaerobically. However, their availability in terms of species abundance and richness is closely related to the types and nature of hydrocarbon contaminants and the surrounding environmental factors [27]. Hence, the availability of naturally occurring suitable bacteria is crucial for the implementation of microbial remedial actions.

6.2. Bacterial Competition and Cooperation. Bacterial cooperation and competition is vital force for survival and stability within microbial communities of a given ecosystem [58]. Hydrocarbon degrading bacterial communities exist in cooperation (with synergistic effect) and/or competition (with antagonistic effect) for their survival in hydrocarbon-contaminated environments [59]. However, the bacterial competition of either interspecific (between bacteria and fungi) or intraspecific (between bacteria species themselves) is a limiting factor for biodegradation efficacy. For instance, for interspecific competition: hydrocarbon-degrading fungi and hydrocarbon metabolizing bacteria can compete to utilize hydrocarbon contaminants as carbon sources and other limited nutrients available (nitrogen and phosphorous) for their growth and metabolism. In addition, some hydrocarbondegrading microbial species also release metabolites that inhibit the growth and development of other hydrocarbondegrading bacterial species [49]. Studies showed that exogenous bacteria (introduced inocula) are used to degrade hydrocarbon contaminants [20] but are not usually effective. This is because they are unable to avoid competition with indigenous bacteria, predators, and various abiotic factors [53]. The study confirmed that the synergistic association between Cycloclasticus and Alcanivorax borkumensis enhances the degradation of polyaromatic hydrocarbons and antagonistic effect between Thalassolituus and other oleophobic bacteria leading to lessen the rate of biodegradation [59]. It was indicated that $A$. borkumensis produces surfaceactive substances (biosurfactant) to increase the emulsification of PAHs to be readily accessible for Cycloclasticus and no competition for PAHs for carbon source since A. borkumensis uses other hydrocarbon contaminants as a metabolite. However, Thalassolituus produces metabolites that can antagonize other oleophilic bacterial growth and development. The study also showed that the coexistence or interaction between indigenous and exogenous microbes antagonistically obstructs the metabolic activities of each other and thereby limits the effectiveness of hydrocarbon biodegradation [9]. Therefore, the interdependence of microbial populations (synergistic effect) is important for the successful application of bioremediation. It has been shown that some hydrocarbondegrading microbial consortia develop synergistic relationships for complete degradation [60]. Thus, the bacterial consortia (community) provide comprehensive perceptions 


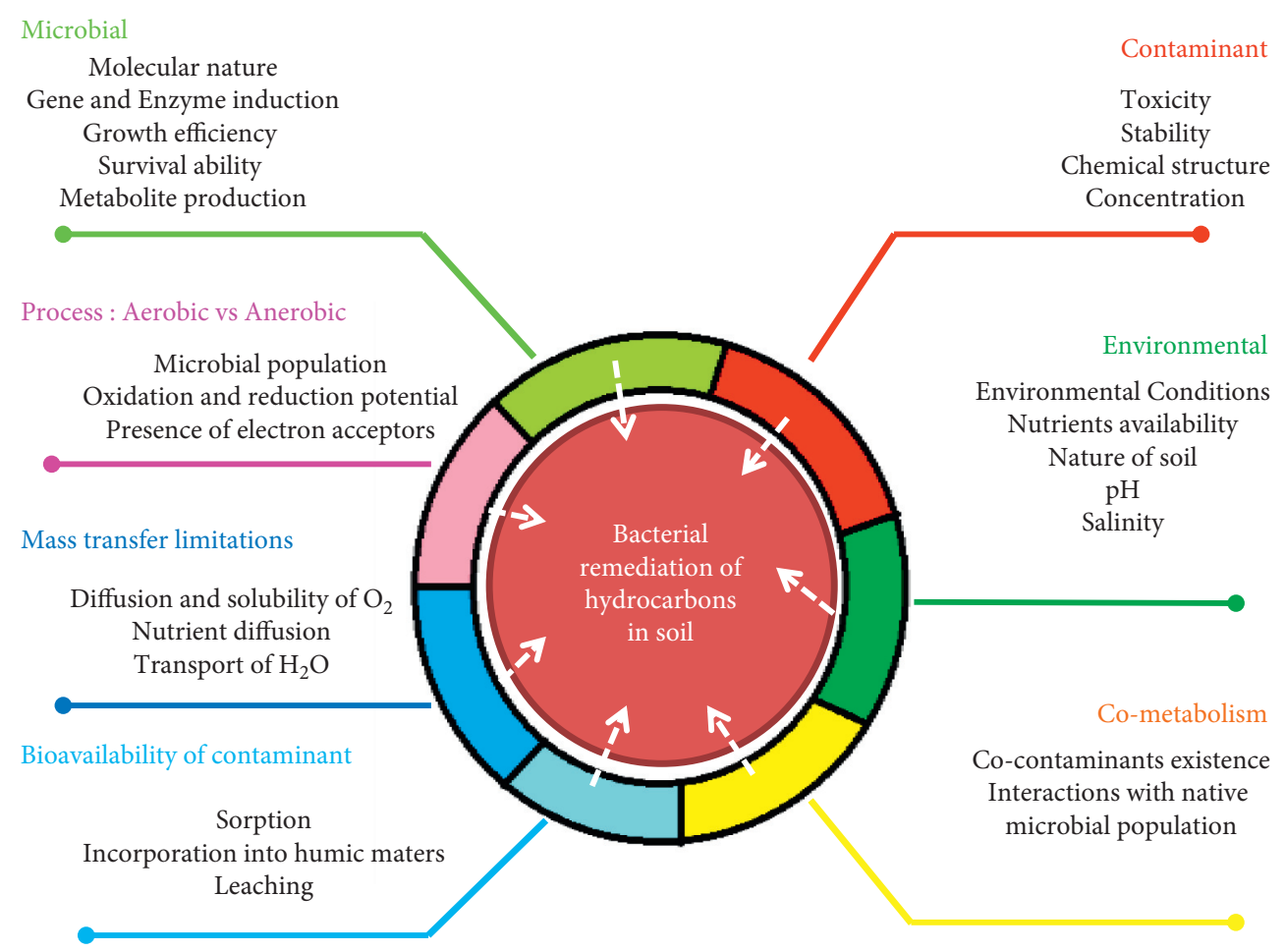

FIGURE 4: Major classes of factors influencing the bacterial remediation of hydrocarbons in soil.

about the modulation of their potential in hydrocarbon biodegradation and can provide useful information for in situ bioremediation of hydrocarbon-related pollutions.

\subsection{Indigenous and Exogenous Hydrocarbon-Degrading} Bacteria. Naturally occurring or introduced microbes (single or microbial communities) may be involved in removing hydrocarbon contaminants. However, native bacterial populations (indigenous and autochthonous) are competent than introduced inocula (exogenous and allochthonous) to mineralize hydrocarbon pollutants for the long-term success of the bioremediation process [61]. The microorganism that possesses a high degree of stability and physiological adaptations (specific catabolic actions) suited to local nutrient availability and environmental conditions is important to degrade various hydrocarbon components from contaminated sites [30]. Indigenous bacteria showed more efficient biodegradation at the rate of about as compared to exogenous consortia [53]. This is because exogenous bacteria are unable to withstand abiotic factors stress and are firm to live and propagate in the soil environment [58]. As a result, using indigenous inocula of specific bacterial strains or microbial consortia isolated from hydrocarbon-contaminated environments acclimates well to the local environment and is suggested for efficient and inexpensive bacterial bioremediation.

6.4. Bacterial Community Structure and Diversity/Microbial Consortia. To develop bioremediation techniques or strategies for hydrocarbon degradation, there is the need to have a better understanding of the dynamics of the bacterial community [62]. The soil environments contaminated with hydrocarbon pollutants change microbial community structure (diversity, richness, and evenness), thereby affecting the metabolic activity of hydrocarbondegrading bacteria [63]. Studies also showed that when hydrocarbon contaminants are introduced to the soil environment, bacterial communities shift and can show instant and significant reductions in some bacterial species, while others became favorably more plentiful [60]. Supporting this, in long hydrocarbon-contaminated sites, the distribution and abundance of microbial communities were found to be in the increasing order of Chlamydiae, Elusimicrobia, Thermi, Cyanobacteria, Verrucomicrobia, Chloroflexi, Acidobacteria, Gemmatimonadetes, Firmicutes, Actinobacteria, Bacteroidetes, and Proteobacteria [5]. Thus, the hydrocarbon-degrading bacterial community structure and diversity showed that bacterial consortium (indigenous or introduced) is efficient than a single strain for complete degradation of hydrocarbon contaminants in the soil $[10,27]$. This is for the reason that a single bacterial isolate (monoculture) can only utilize a limited range of hydrocarbon substrates [64], while mixed bacterial isolates (polyculture and consortium) are efficient to metabolize highly concentrated and broad hydrocarbon contaminants [30]. This is because consortia of bacteria possess broad degradative enzymes, degrade different hydrocarbon components (aliphatic and aromatics), have a higher tolerance to physic-chemical parameters (temperature, $\mathrm{pH}$, and salinity) and a higher rate of surface-active biomolecules (biosurfactants) synthesis, and cope up with synergistic effect to maximize the rate of bioremediation $[65,66]$. 
Therefore, understanding community structure, diversity, and interaction is essential to define the metabolic potential (metabolic diversity) and hydrocarbon specificity of hydrocarbon-degrading communities [48]. In the bacterial consortia, the antagonistic effect of some other bacteria could limit the efficiency of bacterial remediation [67]. Hence, the activities of these antagonistic bacteria have to be controlled to encourage the continued development of viable potential bacterial consortia. Many studies showed that microbial communities (bacteria, fungi, yeasts, and algae) play a great role in the biodegradation of hydrocarbon pollutants $[56,65]$. There are several bacterial genera that are tested for the degradation of hydrocarbon (Table 2). The most known hydrocarbon degrader bacteria belong to the genus of Pseudomonas, Bacillus, Sphingomonas, Rhodococcus, Alcaligenes, and so on [7, 24, 27, 63, 68-71]. Those bacteria can usually metabolize only a limited range of hydrocarbon substrates. Some of them degrade alkanes (normal, branched, and cyclic paraffin) and aromatics while others both paraffinic and aromatic hydrocarbons [68]. Therefore, a bacterial consortium (mixing of potential bacteria) with overall broad enzymatic capacities is required to synergistically degrade complex mixtures of pollutants. Supporting this, studies also showed that consortia of Staphylococcus sp., Stenotrophomonas sp., and Pseudomonas sp. [66]; Pseudomonas sp., Acinetobacter sp., and Rhodococcus sp. [49]; Marinobacter sp. and Roseovarius sp. [71]; Pseudomonas aeruginosa and Rhodococcus erythropolis [57]; Bacillus sp., Corynebacterium sp., and Pseudomonas sp. [65]; Pseudomonas sp., Gordonia sp., Aeromonas sp., Stenotrophomonas maltophilia, Xanthomonas sp., Alcaligenes xylosoxidans, and Rhodococcus sp. [72]; and Stenotrophomonas sp., Bacillus sp., Brevibacillus sp., Nocardiodes sp., and Pseudomonas sp. [70] indicated proficient bioremediation activities. However, the functioning of bacterial community structures and diversity for the complete bioremediation/biodegradation is influenced by hydrocarbon components, nutrients limitation upon competition (TC, TN, TP, and TOM), metabolites produced, soil physicochemical properties, and the compatibility of the mixture during bioremediation [73]. Therefore, using the consortium of potential microbes with overall broad catabolic enzymes and genes, biodegradation may become faster, efficient, and complete.

6.4.1. Biofilm Formation. To survive, bacterial cells form collection in the form of flocks, mats, or biofilm Biofilm weight (up to 90\%) is composed of extracellular matrix and microbial cells [74]. When microbial communities encounter a harsh situation they react with any change of environment (stimuli) by producing extracellular polymers that surround them and facilitate their attachment on the substratum [75]. This is important to change response with respect to their growth, catabolic gene exchange, gene transcription and/or horizontal gene transfer, and an adaptive mechanism for physicochemically harsh conditions and regulate redox state of their environment [32]. Biofilm can be, however, formed by single or groups of microbial
TABLE 2: Bacterial genus reported for hydrocarbon degradation.

\begin{tabular}{|c|c|c|}
\hline S. No. & Bacterial genus & References \\
\hline 1 & Pseudomonas & \\
\hline 2 & Cycloclasticus & \\
\hline 3 & Sphingomonas & \\
\hline 4 & Rhodococcus & \\
\hline 5 & Neptunomonas & \\
\hline 6 & Microbulbifer & \\
\hline 7 & Polaromonas & \\
\hline 8 & Cellulomonas & \\
\hline 9 & Achromobacter & \\
\hline 10 & Gordonia & \\
\hline 11 & Marinobacter & \\
\hline 12 & Actinobacteria & \\
\hline 13 & Deltaproteobacteria & \\
\hline 14 & Dietzia & \\
\hline 15 & Alcaligenes & \\
\hline 16 & Moraxella & \\
\hline 17 & Mycobacterium & \\
\hline 18 & Arthrobacter & \\
\hline 19 & Pasteurella & \\
\hline 20 & Haloarcula & \\
\hline 21 & Marinobacter, & \\
\hline 22 & Flavobacterium & {$[7,24,27,63,68-71]$} \\
\hline 23 & Roseovarius & \\
\hline 24 & Corynebacterium & \\
\hline 25 & Bacillus & \\
\hline 26 & Micrococcus & \\
\hline 27 & Nocardia & \\
\hline 28 & Xanthomonas & \\
\hline 29 & Phanerochaete & \\
\hline 30 & Vibrio & \\
\hline 31 & Anabaena & \\
\hline 32 & Serratia & \\
\hline 33 & Altererythrobacter & \\
\hline 34 & Burkholderia & \\
\hline 35 & Alcanivorax & \\
\hline 36 & Ralstonia & \\
\hline 37 & Alkanibacter & \\
\hline 38 & Paenibacillus & \\
\hline 39 & Aeromonas & \\
\hline 40 & Enterobacter & \\
\hline 41 & Promicromonospora & \\
\hline 42 & Microcella & \\
\hline 43 & Stenotrophomonas & \\
\hline
\end{tabular}

species, and their potential in hydrocarbon biodegradation is tested using some species of bacterial species such as A. borkumensis, Pseudomonas sp., Marinobacter hydrocarbonoclasticus, and Bacillus sp. [76]. Microbial communities that form biofilm are the potential to increase bioaccessibility of the carbon sources from the hydrocarboncontaminated sites by synergistic effects, adapting to a new environment and acquiring metabolic changes to survive in an environment with a limited range of nutrients [75]. The formation of biofilm enhances biodegradation of hydrocarbon polluted soil environment by increasing microbial adaptation to low bioavailability of hydrophobic compounds [60]. This is due to the high microbial biomass within the biofilm being efficient for biosorption (to reduce immobilization of contaminants) as compared to the dispersed 
microbial cell growth in the contaminated sites. Additionally, biofilm formation is vital to provide optimal factors $(\mathrm{pH}$, salt concentration, and redox potential) for effective growth microbial communities and their hydrocarbon biodegradation [32]. Likewise, aggregation of multicellular entities embedded in matrices is important to facilitate hydrocarbon biodegradation by their involvement in flocculation and binding of heavy metals [77]. In addition, the exopolymer serves as a microbial attachment onto surface substratum, regulation of energy transfer and waste production, environmental protection (change in osmolality, temperature, adsorbs metals, and different organic compounds), and mechanical stability. This is because it consists of numerous biological components (polysaccharides, proteins, nucleic acids, lipids, and humic substances), all of which regulate the hydrophobicity, biodegradability, and adsorption properties of the biofilm [74]. Hence, the presence or absence of biofilm formation will enhance or hinder the hydrocarbon biodegradation rates. The more biofilm formation, the more biodegradation rate will be happening.

6.5. Number of Hydrocarbon-Degrading Bacteria. The number (population density) of hydrocarbon-degrading bacteria is a key factor for the degradation of hydrocarbon pollutants in the soil [56]. The number and diversity of potent hydrocarbon-degrading bacteria are relatively fewer than the number of whole naturally available bacteria if the site is not previously contaminated with hydrocarbon contaminants [78]. However, several hydrocarbon-polluted milieus are successfully conquered by hydrocarbondegrading bacteria than other bacteria which do not have hydrocarbon degradation potentials. This variation is important to indicate that the hydrocarbon-degrading bacteria are known to possess effective hydrocarbon degradative enzymes and versatile metabolic pathways. Studies showed that for successful hydrocarbon biodegradation, the number of soil bacteria is usually in the range of $10^{4}-10^{7} \mathrm{CFU}$ per gram of soil, while lower than $10^{3} \mathrm{CFU}$ per gram of soil showed less biodegradation potential [56]. The high population of hydrocarbon-degrading bacteria substantially leads to more degradation rate [64]. Therefore, for having effective bacterial remediation, it is important to determine the number of potential microbes in the contaminated sites.

6.6. Bacterial Metabolic Capability. Bacterial metabolic potential with diverse and appropriate metabolic pathways is a key factor for the degradation, transformation, and mineralization of various hydrocarbon pollutants in the soil [70]. Microbial species that can utilize toxic pollutants are becoming dominant in the contaminated sites [67]. They also develop efficient catabolic activities by producing intracellular or extracellular broad substrate-specific enzymes: oxidoreductases, oxygenases (monooxygenases and dioxygenases), dehydrogenases, hydrolases, peroxidases, peroxidases, and laccases [22, 33], and new metabolic pathways (genetic changes) to degrade hydrocarbon pollutants either aerobically or anaerobically [56]. The genes that encode hydrocarbon degradative enzymes are critical for the potential of microbes to bioremediate soils contaminated with hydrocarbon pollutants [60] and identified from various kinds of hydrocarbon-degrading Grampositive and negative bacteria [16]. Such overall possibilities are controlled by catabolic plasmids (known as chromosomal or plasmid DNA) and codified by genes for specific physiological functions. The genes such as ass $A$, bssA, phe, nahAc, xylE, PAH-RHD $\alpha$, GN-RHD $\alpha$, phd, nag, phn, nar, nid, alkB, TOL, ndoB, alkM, alkB1, alkB2, nahH, SAL, pND50, Alma, C230, PAH-RHD(GP), nahAC, $p W W 31, p J P 1, p J P 4, p K F 1, p A C 21, p R E 1, p A C 25, p W R 1$, and $p C S 1$ are reported to encode many aromatic compound degradations [14, 55, 78, 79]. Those various genes were identified in various bacterial genera such as Pseudomonas sp., Sphingomonas sp., Comamonas sp., Alcaligenes sp., Acinetobacter sp., Burkholderia sp., Rhodococcus sp., Nocardioides sp., Mycobacterium sp., Klebsiella pneumoniae, Enterobacter cloacae, Bacillus pumilus, and Burkholderia sp. [18, 79].

Most hydrocarbon-degrading bacteria, on the other hand, are unable to catabolize all types of hydrocarbon compounds. This is due to the fact that they have specialized hydrocarbon-degrading enzymes. As a result, some can digest aliphatic hydrocarbons, while others can only break down aromatics (mono and/or poly), with just a few microbes possessing physiologically diverse metabolic capacity [59]. For metabolically active bacteria, aerobic and anaerobic hydrocarbon metabolisms are studied [80]. For aerobic metabolic pathways, hydrocarbon-degrading bacteria are known to use either monooxygenase (incorporate one $\mathrm{O}_{2}$ atom) or dioxygenase (incorporate two atoms of $\mathrm{O}_{2}$ ) enzymes for the metabolism of aliphatic and aromatic hydrocarbons. Most microorganisms use monooxygenases to oxidize alkanes by attacking terminally, biterminally, or subterminally for the production of alcohol and further oxidize to aldehyde and fatty acid and finally get into Kreb's cycles via $\beta$-oxidation process $[80,81]$. Some other potential microorganisms use dioxygenases (alkane monooxygenase, ring-hydroxylating dioxygenases, and catechol dioxygenase) to degrade aromatic hydrocarbons using either ortho or meta ring fission mechanisms, and the products are further metabolized to tricarboxylic acid cycle intermediates and sooner or later mineralized to $\mathrm{CO}_{2}$ and $\mathrm{H}_{2} \mathrm{O}$ [18]. For anaerobic pathways, both aliphatic and aromatic hydrocarbon contaminants can be oxidized into phenolic compounds or organic acids and then changed into a long chain of volatile fatty acids to end with methane and carbon dioxide [80]. Consequently, microbial catabolic activities are the major factors limiting or promoting biodegradation depending on the type of metabolic pathways that the microbes enjoy and the nature of the contaminants. Additionally, the numbers of different bacterial genes are important to judge the contamination level and natural degradation capacity.

6.7. Redox Potential of the Bacteria. Bacteria require energy for biological functions, cell maintenance, and reproduction. Physiologically, this energy is produced within bacterial cells via a redox reaction [51]. Bacteria, therefore, catabolize 
hydrocarbon pollutants as the source of energy by catalyzing the transfer of electrons from electron donors to electron acceptors in aerobic or anaerobic bioremediation. This phenomenon depends on redox potentials that are important to drive the oxidation of hydrocarbon-derived pollutants for bacterial energy production (respiration) and enhance their growth by reducing the redox potential. Studies showed that many organic pollutants like hydrocarbon have a low rate of degradation due to their high redox potential [82]. Thus, the redox potentials show oxidizing or reducing conditions, provide an indication of the relative dominance of the electron acceptor (oxygen, nitrate, sulfate, iron (III), manganese, chlorate, perchlorates, etc.) [8, 51, 83], and require an energy source (electron donor) and nutrients for bioremediation processes. For aerobic conditions, oxygen does not only act as a final electron acceptor but is also important to enzymatic activation of aromatic hydrocarbon as mono or dioxygenases. As a result, aromatic compounds are favorable electron donors for bacterial growth because of the high Gibbs free energy change of the oxidation of these compounds with different electron acceptors [83]. In addition, for anaerobic conditions, the substances that have high reduction potential (e.g., perchlorate and chlorate) make them ideal electron acceptors for microbial metabolism during bioremediation processes.

When hydrocarbon-degrading bacteria grow well with decreasing pollutant, content is associated with the redox potential of the electron acceptors [84]. In highly contaminated sites, the electron donors (hydrocarbon) are excess over the oxidation potential of electron acceptors. Consequently, the respiration and biodegradation process can be controlled by the availability of specific electron acceptors [85]. Accordingly, bacterial degradation can be limited due to the low redox potential and depletion of electron acceptors. This is because the lower redox potential results in anoxic conditions and reduces the rate of biodegradation [86]. In general, the presence of dominant electron acceptors in hydrocarbon-contaminated sites is an important factor affecting the rate of biodegradation.

6.8. Effect of Biosurfactant. When hydrocarbon pollutants are released into the soil, they become difficult to biodegrade. This is due to their firm adsorption to soil matrices and less or no bioavailability for microbial biodegradation [67]. To overcome this problem, the uses of inorganic and organic surface-active agents have been exercised [7, 87]. The chemically synthesized surfactants have been used to improve the solubility of hydrocarbons through the process called emulsification. For this, treatment hydrocarbon contaminants using ionic (anionic and cationic), nonionic, biological, and mixed surfactants were used [2]. However, chemically synthesized (inorganic) surfactants were not recommended for further use since they are also prone to secondary contamination and are mostly hazardous to the environment with minimal or no effect on hydrocarbon biodegradation efficiency [71]. This indicates that the use of biosurfactants obtained from natural sources (plants or microorganisms) showed efficient activities and is acceptable since they are biodegradable, nontoxic, specificity under extreme circumstances, and more appropriate for hydrocarbon degradations [50]. As part of this, hydrocarbon-degrading bacteria produce those surface-active biological molecules extracellularly to emulsify and easily uptake the hydrocarbon contaminants $[32,57,81,88]$. There are many kinds of biosurfactants such as glycolipids (rhamnolipids, emulsans, liposans, sophorolipids, and trehalolipids), lipopeptides and lipoproteins, surfactin, lichenysin, fatty acids, polymeric biosurfactants, phospholipids, and neutral lipids. They are produced from various microbes such as Bacillus sp., Pseudomonas sp., Aeromonas sp., Enterobacter sp., Burkholderia sp., Acinetobacter sp., Micrococcus sp., Rhodococus sp., and some halophile species [33, 57, 69, 81, 88, 89].

Biosurfactant enhances hydrocarbon degradation in many ways, including by modulating the solubilization and desorption of pollutants as well as modification of bacteria cell surface properties. Biosurfactants are capable of lowering the surface tension and the interfacial tension of the water/air or water/oil interface [32]. Thus, the surface area of the hydrocarbon substrate increases, making emulsification easier, and the entire phenomena make the substrate to be readily available for uptake and metabolism [55]. Additionally, the reduction of the interfacial tension leads to increased penetration of porous materials via the aqueous phase. Biosurfactants forms micelles in aqueous solutions at a concentration exceeding critical micelles concentration (CMC) [19]. To display the lowest surface tension, the hydrophobic part boosts the exploitation and solubilization of hydrocarbon contaminants into the solution. However, the CMC of surfactants and their effectiveness for the removal of hydrocarbon pollutants may be entirely dependent on their nature, type, composition, ionic strength, the physicochemical characteristics of the reaction mixture, and other factors [2]. In addition, the uses of biosurfactants also enhance the expression of siderophores production (metal-binding peptides) and biofilm formation for hydrocarbon biodegradation [77]. Overall, biosurfactants are capable to increase the solubility, mobility, dispersion, bioavailability, and degradability of hydrocarbon pollutants [3]. Therefore, for efficient hydrocarbon bioremediation, fulfilling and optimization of the bacterial growth parameters are not enough without consideration of the capacity of the bacteria to produce appropriate biosurfactants.

\section{Abiotic Factors}

\subsection{Hydrocarbon Characteristics}

7.1.1. The Physical and Chemical Nature of the Contaminant. Microbial bioremediation strategy is always needed to infer the interaction between the potential microbes and the hydrocarbon pollutants. The physical (heaviness, occurrence, diffusion rate, and viscosity) and chemical properties (components, molecular weight, and structures) of the hydrocarbon pollutants can affect biodegradation, transportation, and metabolism of a single strain or consortia of bacteria. This is due to the molecular size, composition, structure, concentration, toxicity, and unpredicted products 
of hydrocarbon in the contaminated environment. These conditions affect the occurrence, stability, and biological activities of hydrocarbon-degrading bacteria. In addition, the high molecular weight of polyaromatic hydrocarbons (four or more rings: pyrene, chrysenes, fluoranthene, benzo [a] pyrene, and coronenes), and highly condensed cycloalkane compounds are recalcitrant than unbranched alkanes (intermediate length: $\mathrm{C}_{10}-\mathrm{C}_{25}$ ) and lighter PAHs (two or three rings: naphthalene, phenanthrene, and anthracene) to microbial degradation $[77,90]$. This means the rate of hydrocarbon biodegradation of $n$-alkanes $>$ branched alkane's $>$ low-molecular-weight aromatics $>$ high molecular weight of aromatic hydrocarbons $>$ asphaltenes $[8,80]$. The nondegradation prospective of the contaminant is because their nature accounts for their solubility, bioavailability, toxicity to microbes by the disruption of the lipid membrane, and unable to cleave the ring for degradation. Therefore, understanding the chemical characteristics, physical state (heterogeneity and degree of spreading), and toxicity, and the fate (physical, chemical, and biological change) of hydrocarbon contaminants is mandatory to determine the rate of hydrocarbon biodegradation [56].

7.1.2. Hydrocarbon Concentration. The concentrations of hydrocarbon pollutants affect the rates of uptake, transformation, and mineralization of bacterial biodegradation. Extremely high concentrations are known to be toxic and negatively influence the growth rate and biomass production of degraders and require a long treatment duration [91] due to the heavy and undispersed nature of high concentration pollutants [66]. In addition, it was confirmed that hydrocarbon concentration $>5 \%$ decreases microbial degradation activity and may interrupt C:N:P ratio and oxygen availability [54]. Similarly, extremely low concentrations of hydrocarbons limit biodegradation by suppressing bacterial metabolic genes not to produce degradation enzymes and causes low supply or unavailability of carbon to support microbial growth [51]. Therefore, bacterial biodegradation of hydrocarbon depends on the presence of optimum concentration (not too high or low) for complete mineralization from contaminated environments.

7.1.3. Bioavailability of the Hydrocarbon Contaminants. According to Maletić et al. [47], the term bioavailability is defined in many ways: it refers to an interactions between pollutants and living cells, the degree to which pollutants in the soil may be absorbed or metabolized, maximum quantity of a contaminant available for uptake by an organism within a given time period, and the chemically active compound on its way to a degrader organism. In general, the bioavailability of hydrocarbon pollutants refers to the number of hydrocarbon substrates that are abundantly accessible to potential microbes $[4,58]$, and it is a rate-limiting factor in biodegradation processes [3]. However, the bioavailability is of pollutants can be restricted because of their high hydrophobicity, low water solubility (high molecular weight), low concentration, low diffusion rate, desorption onto soil and inorganic matrix colloids, chemical structures, temperature, viscosity, duration of the contamination, and soil characteristics (particle size and types of soil) [7]. For instance, at low temperature, viscosity and solubility of pollutant decreases; ice formation in the soil increases; and the transfer of oxygen, nutrients, and hydrocarbon in the soil (bioavailability) decreases. These lead to low accessibility for bacterial metabolism. Hence, the lack of bioavailability of hydrocarbon contaminants in the soil is a major factor inhibiting the rate of their biodegradation rate. This ratelimiting factor can be partially overcome by the use of biosurfactants, which increase the bioavailability of hydrocarbons. In a few cases, however, the biosurfactants can inhibit bacteria, and thus, the effect of the biosurfactant depends on the physicochemical properties of the biosurfactants, the types of pollutants, and the physiological properties of the functional microorganisms [27]. In this view, selection of biosurfactants is important, and several species of bacteria, such as Bacillus sp. DQ02 and Bacillus amyloliquefaciens An6, showed improved degradation efficiency with biosurfactants [19].

\subsection{Physical Parameters}

7.2.1. Soil Characteristics. The soil is the most multifaceted environment to harbor various kinds and populations of microorganisms. Its environmental factors (physicochemical properties) are the determinant stimuli for the nature of indigenous microbes, bacterial community, and the composition of functional genes [73]. The soil physicochemical characteristics that show such effect include soil type, region, texture, particle size, maximum water holding capacity (moisture), temperature, nutrient content, oxygen content, and $\mathrm{pH}[6,91]$. Overall, those soil factors are affecting the chemical stability, bioavailability, and movement of hydrocarbons pollutants in the soil to support potential bacterial growth and then ultimately for effective biodegradation [11].

7.2.2. Soil Region. The topsoil (surface soil, vadose zone, and unsaturated zone of soil) predominantly harbors a high population of bacteria due to the regular supplement of organic matters (from plants and animals) and adequate oxygen availability. Contrarily, in sediments (saturated zone of soil), there is a low bacterial population due to the decrease in organic matter supplement and oxygen availability with an increase in soil depth [59]. Therefore, the soil region affects the number and community of bacterial population in the hydrocarbon-contaminated soil.

7.2.3. Soil Particle Size. The size of the soil particle also determines the soil permeability and rate of hydrocarbon biodegradation [92]. Fine soil particles (clay soil; with small interstitial spaces) retain the hydrocarbon at the soil surface and reduce the availability of nutrients and oxygen whilst coarse soil particles (sand soil; with large interstitial spaces) drain hydrocarbon pollutants through the soil to the unsaturated zone. Those properties of soil make the rate of 
hydrocarbon biodegradation very sluggish [6]. Hence, for efficient and rapid biodegradation, abstemiously drained soil particles (increase in porosity) are important for intensification of the contaminant's bioavailability, supply of oxygen, and enhancing the metabolism and growth of potential indigenous microbes [22].

7.2.4. Nutrient Availability. Bacteria require nutrients for their metabolism and growth, and therefore, the microbial community is dependent on nutrient accessibility in the hydrocarbon-contaminated natural soil environment [5]. In a natural environment, the hydrocarbon-degrading bacteria are regulated by inorganic nutrients as limiting factors [62]. This implies that the presence or addition of macronutrients $(\mathrm{N}, \mathrm{P}$, and $\mathrm{K})$ in the contaminated soil increases the biostimulation [91] and determines the distribution and degradation of hydrocarbon pollutants [65]. Organic matter in the soil is a source of nutrients and enhances some properties of soil to promote the growth and activities of soil microbes [93]. Thereby, treatment of the soil with poultry manure alone can enhance oil degradation [94]. Besides, a high accumulation of organic nutrients leads to the toxicity of soils due to the production of toxic intermediates during hydrocarbon biodegradation [95]. Even though those hydrocarbon-degrading bacteria use hydrocarbons as an excellent source of carbon and energy, access to other nutrients such as nitrogen and phosphorus is limited from the contaminant itself. When there is a large accumulation of organic carbon contents in the hydrocarbon-contaminated sites, there is the rapid depletion of other inorganic nutrients such as nitrogen, phosphate, and potassium ( $\mathrm{N}, \mathrm{P}$, and $\mathrm{K}$ ) and trace amounts of calcium, sulfur, magnesium, iron, and manganese due to rapid microbial metabolic activities. This limits the rate and extent of hydrocarbon biodegradation and biotransformation. To avoid such limitation, studies recommended adjustment of carbon/nitrogen/phosphorous $(\mathrm{C} / \mathrm{N} / \mathrm{P})$ ratio to $100: 10: 1$ [96] to $100: 20: 1$ [58, 91] for considerable hydrocarbon biodegradation. This can be applied by the addition of urea, phosphate, $\mathrm{N}-\mathrm{P}-\mathrm{K}$ fertilizers, and ammonium, and phosphate salts are mandatory [56]. It has been demonstrated that concentrations of phenanthrene did not change significantly without supplement of inorganic fertilizer (nitrogen and phosphorous) but decreased greater than 25 times in soil amendment [79]. Even though some bacteria exhibit good growth or adaptation for the high amount of carbon, nitrogen, potassium, and phosphorus sources in hydrocarbon-contaminated sites, biostimulation (extra supplement of nutrients or fertilizers) significantly affects indigenous microbial communities [12]. This reduces the rate of degradation by suppressing microbial growth and production of enzymes and ultimately resulting in toxicity to soil microbes $[29,61]$. In addition, high concentration hydrocarbon contaminants could also alter the NPK ratio and thus ultimately resulting in oxygen shortage. In general, improper supply (excessive or low) and/or absence of mineral nutrients limit the growth of hydrocarbon utilizing bacteria in the soil. Therefore, the supplement of optimal level of nutrients ( $\mathrm{N}$ and $\mathrm{P}$ ) in contaminated soils is indispensable for effective hydrocarbon biodegradation $[25,64,92]$. The hydrocarbon biodegradation is, therefore, depends on soil environment amendments, and in that way, the maximum degradation rate can be enhanced with the addition of nutrients to the optimal level.

7.2.5. Aeration/Oxygen Availability. Hydrocarbon degrading bacteria (oleophilic) can respire with the presence of oxygen (aerobic) and the absence of oxygen (aerobic or facultative). The availability of molecular oxygen in the soil is the limiting factor for aerobic bioremediation and acts as the final electron acceptor [28] and chemical reactant (the enzymatic oxygenase reactions) for a terminal, subterminal, and biterminal oxidation and ring cleavage of aromatic hydrocarbon contaminants [15]. The study indicated that without considering the total biomass of potential hydrocarbon-degrading bacteria, $3.1 \mathrm{mg} / \mathrm{ml}$ of oxygen is required for the degradation of $1 \mathrm{mg} / \mathrm{ml}$ hydrocarbon contaminants [54], and 10-40\% of oxygen level is required for effective hydrocarbon biodegradation [28]. It is, therefore, aerobic catabolism results higher biodegradation rate than anaerobic metabolism [97, 98]. Reports showed that the use of isolated bacterial strains degraded $20-25 \%$ of the total amount of oil under aerobic conditions within 10 days, but the same strains took 50 days under anaerobic conditions to degrade $15-18 \%$ of the total petroleum present [68] and no or diminutive hydrocarbon pollutant degradation in anoxic soil region [77]. However, the low level of oxygen in hydrocarbon-contaminated sites hampers the aerobic degradation routes and resulting low removal efficacy [30]. The factors resulting in slow biodegradation and free oxygen depletion in the soil include oxygen concentration, bacterial oxygen consumption rate, physical and chemical properties of contaminated soils (type and porosity), and the presence of utilizable substrates or accumulation of organic matters $[6,28]$. Therefore, the availability of oxygen in the soil is essential to have effective biodegradation.

7.2.6. Effect of Temperature. The temperature has a significant effect on the rate of bacterial growth, the activity of the enzymes, the chemistry of the pollutants, physiology, and diversity of the bacterial community responsible for degradation processes $[15,51]$. Thus, temperature is considered an important factor in biological remediation, and the efficiency of removing hydrocarbon pollutants is directly related to temperature. Liu et al. [62] reported that temperature played a significant role in selecting petroleum hydrocarbon-degrading bacteria in deep and surface waters of the Northern Gulf of Mexico, besides water chemistry and the initial microbial community. The community of bacteria associated with hydrocarbon degradation is linked to temperature fluctuation and is that moderate temperatures are generally attributable for selecting mesophilic hydrocarbondegrading bacteria. Several hydrocarbon-degrading bacteria were also shown to have a wide range of degradation effectiveness, suggesting the importance of temperature in remedial methods for the remediation of hydrocarbon contamination [27]. 
Additionally, studies indicated that the rate of hydrocarbon degradation is dependent on the temperatures of the region (tropical, temperate, and arctic) of contaminated sites [31]. For instance, psychrophiles require below $20^{\circ} \mathrm{C}$; mesophiles require between $15-45^{\circ} \mathrm{C}$; and thermophiles require above $50^{\circ} \mathrm{C}$ for hydrocarbon metabolism [56]. As temperature increases, solubility, bioavailability, diffusion, and enzymatic activities of microorganisms also increase [98], whereas, at a higher temperature (above $40^{\circ} \mathrm{C}$ ), oxygen solubility decreases, and metabolic activity of aerobic bacteria diminishes; the membrane becomes more susceptible to hydrocarbon toxicity and consequently reduces the hydrocarbon biodegradation rate $[56,68]$. Conversely, at lower temperatures, the oil viscosity increases; the volatility of low-molecular-weight of toxic hydrocarbons pollutants decreases; solubility decreases; the toxicity of low-molecular-weight of hydrocarbons increases; rates of enzymatic activity decreases; and hence, there is a delay microbial biodegradation [52]. Indeed, the degradation efficiency of hydrocarbons at lower temperatures could be improved with biosurfactants by influencing the viscosity and solubility of hydrocarbons. In addition, studies have shown that the maximum rates of microbial hydrocarbon degradation occur in a warm environment [31], particularly in the range of $30-40^{\circ} \mathrm{C}[52,97]$. In general, the rate of biodegradation decreases with decreasing temperature, while it accelerates with increasing temperature. As a result, potential bacteria need an optimal temperature range for complete hydrocarbon degradation.

7.2.7. Effect of $p H$. Soil $\mathrm{pH}$ (neutral, acidic, or alkaline) affects bacterial growth and bioremediation strategies. Most hydrocarbon-degrading bacteria favor neutral $\mathrm{pH}$ [98] to slightly alkaline [97]. The production and accumulation of bacterial waste products can change the $\mathrm{pH}$ of hydrocarbon-contaminated soils and consequently influences nutrient availability, solubility contaminant, bioavailability, and microbial activities. Studies showed that hydrocarbons can be minimally degraded with a range of $\mathrm{pH} 2-5.5$ and alkaline $\mathrm{pH} 7.5-10[54,56]$, while effective hydrocarbon degradation is obtained at nearly neutral $\mathrm{pH}$ (5.2-7.0) [79] and the greatest bacterial population observed at $\mathrm{pH} 7.5$ too [99]. Another study also recommended that for optimum hydrocarbon bioremediation soil, $\mathrm{pH}$ range will be 6-8 [98]. From the literature, it is found that a little change in $\mathrm{pH}$ can dramatically affect the rate of hydrocarbon biodegradation [61]. This is because the optimum soil $\mathrm{pH}$ is important to regulate microbial biomass and enzyme activity and boost hydrocarbon biodegradation [99]. Hence, it is important to adjust the soil $\mathrm{pH}$ in hydrocarbon-contaminated sites shall optimally ranging from 5 to 8 for having the greatest effect of bioremediation.

7.2.8. Effect of Moisture Availability. Soil moisture (water film) serves as the transport medium for soil nutrients and the removal of bacterial metabolic waste products in the soil particles. It affects hydrocarbon bioavailability, aeration status, nature and amount of soluble materials, osmotic pressure, diffusion processes, transfer of produced gases, soil toxicity level, and the $\mathrm{pH}$ of the soil $[92,93]$.
When the soil has hydrocarbon contaminants, its porosity and water holding capacity are reduced [22]. Ultimately, this condition decreases microbial activity since bacterial and soil water activities are directly proportional, that is, as moisture content decreases, bacterial activities too decrease, and contrariwise, when the soil moisture level is high, it limits oxygen transfer [63]. That is why hydrocarbon degradation in terrestrial ecosystems is limited by the availability of water for microbial growth and metabolism. Therefore, the proper moisture availability is essential for hydrocarbon biodegradation and in the range of 50-75\% [95], 30-90\% [98], and 50-80\% [21]. However, extreme moisture conditions are unfavorable for microbial growth and metabolism. This is because the diffusion of oxygen in the soil is decreased and aerobic hydrocarbon degradations are limited rather than making anaerobic soil environments. Hence, providing proper moisture (water availability) in hydrocarbon-contaminated sites is mandatory to boost microbial activities for hydrocarbon degradations.

7.2.9. Effect of Salinity. The deposition and accumulation of salt naturally or anthropologically affect microbial hydrocarbonoclastic activity and increase stress for organisms (halophile or halotolerant) in their habitat [69]. High salt concentration can increase osmotic pressure and hinder microbial metabolic activities, solubility, and transportation systems for essential ions [55] and bring a lack of oxygen for microbes [97]. This might be happened due to the introduction of a large number of soluble fertilizers (nitrates or ammonium salts) and discharging of saline solution into soil. When such hypersaline environments are contaminated with petroleum compounds, halophilic bacteria have the potential to survive and degrade the pollutants. Those potential bacteria have genes encoding hydrocarbonoclastic enzymes, which are responsible for their versatile hydrocarbon catabolism [69]. Studies indicated that significant hydrocarbon degradation was detected with $0.1-2 \mathrm{M} \mathrm{NaCl}$ but maximally $0.4 \mathrm{M}$ and a high level of soil salinity decreased the rate and extent of hydrocarbon biodegradation [56]. In addition, the supplement of salts such as $\mathrm{NaCl}$ and $\mathrm{NH}_{4} \mathrm{Cl}$ in nutrient scarce soil enhances the microbial degradation of hydrocarbons [96]. This is because of the presence of such salts, hydrocarbon biodegradation in soil increased with increasing cation concentrations. However, the higher cation concentrations impede the microbial consortium in the soil and reduce microbial biodegradation of hydrocarbon contaminants [100]. Therefore, identification of proper salt concentration depends on hydrocarbon-contaminated soil environments and the nature of potential hydrocarbon-degrading bacteria.

\section{Summary and Future Outlook}

Hydrocarbon contaminants are considered a serious issue among environmental pollutants due to their high toxicity to human and environmental health. Several studies have shown that microorganisms can break down hydrocarbons utilizing a wide range of enzymes. The process can start in 
contaminated sites whenever biotic and abiotic factors permit. As a result, it is essential to understand the role of biotic (the number, type, and composition of bacterial populations, microbial completion, bacterial redox potential, biosurfactant production, and genetic factors) and abiotic factors (the physicochemical properties of contaminant and environmental variables including bioavailability, nutrient, temperature, $\mathrm{pH}$, aeration, and salinity) for effective contaminant removal. Therefore, for having effective hydrocarbon biodegradation, it is important to optimize environmental factors to allow optimum bacterial growth and metabolism. Furthermore, developing novel biosurfactants that improve the bioavailability of hydrocarbons to bacteria seems to be a promising strategy for overcoming the barrier to microbial absorption of petroleum hydrocarbons. Even though several rate-limiting factors have been elucidated in the current review, the interactive nature of microorganisms, hydrocarbons, and environment still is not completely understood, and further research is necessary to improve predictive understanding of the fate of hydrocarbon pollutants in the environment and the role of microorganisms in biodegradative environmental decontamination. Future research should also focus on establishing a microbial consortium capable of acting on a broad range of hydrocarbons, including saturates, aromatic (mono and polycyclic), resins, and asphaltenes. Various molecular tools such as metagenomics could help uncover the community assemblage residing in unusual hydrocarbon-contaminated environments. Ultimately, synthetic biology technology may be used to produce engineered bacteria with enhanced metabolic abilities and greater potential to break down hydrocarbons pollutants and thus ameliorating the current time-consuming hydrocarbon bioremediation process.

\section{Data Availability}

The data supporting this review are from previously reported studies and data sets, which have been cited.

\section{Conflicts of Interest}

The authors declare no conflicts of interest.

\section{Acknowledgments}

The authors wish to acknowledge all who had been instrumental in the creation of this review article. This review work did not receive any specific grant from funding agencies in the public, commercial, or not-for-profit sectors.

\section{References}

[1] K. Prathyusha, Y. S. Y. V. Jagan Mohan, S. Sridevi, and B. V. Sandeep, "Isolation and characterization of petroleum hydrocarbon degrading indigenous bacteria from contaminated sites of Visakhapatnam," International Journal of Advanced Research, vol. 4, no. 3, pp. 357-362, 2016.

[2] A. A. Befkadu and Q. Chen, "Surfactant-enhanced soil washing for removal of petroleum hydrocarbons from contaminated soils: a review," Pedosphere, vol. 28, no. 3, pp. 383-410, 2018.

[3] N. Mulani, A. B. Fulke, E. D’Souza et al., "Biodegradation of crude oil using marine Bacillus species from Vadinar coast, Gujarat, India," Current Science, vol. 112, no. 3, pp. 569-576, 2017.

[4] C.-H. Chen, P.-W. G. Liu, and L.-M. Whang, "Effects of natural organic matters on bioavailability of petroleum hydrocarbons in soil-water environments," Chemosphere, vol. 233, pp. 843-851, 2019.

[5] S. Kuppusamy, P. Thavamani, M. Megharaj, K. Venkateswarlu, Y. B. Lee, and R. Naidu, "Pyrosequencing analysis of bacterial diversity in soils contaminated longterm with PAHs and heavy metals: implications to bioremediation," Journal of Hazardous Materials, vol. 317, pp. 169-179, 2016.

[6] M. Rafiee, M. Jahangiri Rad, and A. Afshari, "Bioaccumulation and translocation factors of petroleum hydrocarbons in Aeluropus littoralis," Environmental Health Engineering and Management, vol. 4, no. 3, pp. 131-136, 2017.

[7] W. Smułek, M. Sydow, J. Zabielska-Matejuk, and E. Kaczorek, "Bacteria involved in biodegradation of creosote $\mathrm{PAH}$ - a case study of long term contaminated industrial area," Ecotoxicology and Environmental Safety, vol. 187, pp. 1-10, 2020.

[8] A. Imam, S. K. Suman, D. Ghosh, and P. K. Kanaujia, "Analytical approaches used in monitoring the bioremediation of hydrocarbons in petroleum-contaminated soil and sludge," TRAC Trends in Analytical Chemistry, vol. 118, pp. 50-64, 2019.

[9] H. Liu, X. Tan, J. Guo, X. Liang, Q. Xie, and S. Chen, "Bioremediation of oil-contaminated soil by combination of soil conditioner and microorganism," Journal of Soils and Sediments, vol. 19 pages, 2020.

[10] M. T. Bidja Abena, T. Li, M. N. Shah, and W. Zhong, "Biodegradation of total petroleum hydrocarbons (TPH) in highly contaminated soils by natural attenuation and bioaugmentation," Chemosphere, vol. 234, pp. 864-874, 2019.

[11] Z. Aldisi, S. Jaoua, D. Al-Thani, S. Almeer, and N. Zouari, "IsolationScreening and activity of hydrocarbon-degrading bacteria from harsh soils," in Proceedings of the World Congress on Civil, Structural, and Environmental Engineering (CSEE'16), Prague, Czech Republic, March 2016.

[12] A. Shahi, S. Aydin, B. Ince, and O. Ince, "Evaluation of microbial population and functional genes during the bioremediation of petroleum-contaminated soil as an effective monitoring approach," Ecotoxicology and Environmental Safety, vol. 125, pp. 153-160, 2016.

[13] R. Han, B. Zhou, Y. Huang, X. Lu, S. Li, and N. Li, "Bibliometric overview of research trends on heavy metal health risks and impacts in 1989-2018," Journal of Cleaner Production, vol. 276, Article ID 123249, 2020.

[14] C. B. Ehis-Eriakha, C. B. Chikere, and O. Akaranta, "Functional gene diversity of selected indigenous hydrocarbon-degrading bacteria in aged crude oil," International Journal of Microbiology, vol. 2020, pp. 1-11, 2020.

[15] E. Koshlaf and A. Ball, "Soil bioremediation approaches for petroleum hydrocarbon polluted environments," AIMS Microbiology, vol. 3, no. 1, pp. 25-49, 2017.

[16] Q. Liu, J. Tang, X. Liu, B. Song, M. Zhen, and N. J. Ashbolt, "Vertical response of microbial community and degrading genes to petroleum hydrocarbon contamination in saline 
alkaline soil," Journal of Environmental Sciences, vol. 81, pp. 80-92, 2019.

[17] S. K. Singh and A. K. Haritash, "Polycyclic aromatic hydrocarbons: soil pollution and remediation," International journal of Environmental Science and Technology, vol. 16, no. 10, pp. 6489-6512, 2019.

[18] G. Zafra, R. Regino, B. Agualimpia, and F. Aguilar, "Molecular characterization and evaluation of oil degrading native bacteria isolated from automotive service station oil contaminated soils," Chemical Engineering Transactions, vol. 49, pp. 511-516, 2016.

[19] H. Ben Ayed, N. Jemil, H. Maalej, A. Bayoudh, N. Hmidet, and M. Nasri, "Enhancement of solubilization and biodegradation of diesel oil by biosurfactant from Bacillus amyloliquefaciens An6," International Biodeterioration and Biodegradation, vol. 99, pp. 8-14, 2015.

[20] A. M. A. Essabri, N. P. Aydinlik, and N. E. Willia, "Bioaugmentation and biostimulation of total petroleum hydrocarbon degradation in a petroleum-contaminated soil with fungi isolated from olive oil effluent," Water, Air, and Soil Pollution, vol. 230, no. 76, pp. 1-16, 2019.

[21] S. Varjani and V. N. Upasani, "Influence of abiotic factors, natural attenuation, bioaugmentation and nutrient supplementation on bioremediation of petroleum crude contaminated agricultural soil," Journal of Environmental Management, vol. 245, pp. 358-366, 2019.

[22] Y. Huang, H. Pan, Q. Wang, Y. Ge, W. Liu, and P. Christie, "Enrichment of the soil microbial community in the bioremediation of a petroleum-contaminated soil amended with rice straw or sawdust," Chemosphere, vol. 224, pp. 265-271, 2019.

[23] M. Pattabhiramaiah, M. Shanthala, S. Rajashekara, F. Sheikh, and S. Naik, "Biodegradation of polycyclic aromatic hydrocarbons (PAHs) by microbes isolated from the marine sponge biemna fortis (topsent 1897)," Microbial Action on Hydrocarbons, Springer, Singapore, 2018.

[24] A. Sawadogo, H. C. Otoidobiga, L. W. Nitiema, A. S. Traoré, and D. Dianou, "Optimization of hydrocarbons biodegradation by bacterial strains isolated from wastewaters in Ouagadougou, Burkina Faso: case study of SAE 40/50 used oils and diesel," Journal of Agricultural Chemistry and Environment, vol. 5, no. 1, pp. 1-11, 2016.

[25] S. Varjani, V. N. Upasani, and A. Pandey, "Ioremediation of oily sludge polluted soil employing a novel strain of Pseudomonas aeruginosa and phytotoxicity of petroleum hydrocarbons for seed germination," The Science of the Total Environment, vol. 737, pp. 1-8, 2020.

[26] Y. Zhang, C. Peng, Z. Guo, X. Xiao, and R. Xiao, "Polycyclic aromatic hydrocarbons in urban soils of China: distribution, influencing factors, health risk and regression prediction," Environmental Pollution, vol. 254, Article ID 112930, 2019.

[27] X. Xu, W. Liu, S. Tian et al., "Petroleum hydrocarbondegrading bacteria for the remediation of oil pollution under aerobic conditions: a perspective analysis," Frontiers in Microbiology, vol. 9, Article ID 2885, 2018.

[28] M. A. Clarkson and S. I. Abubakar, "Bioremediation and biodegradation of hydrocarbon contaminated soils: a review," IOSR Journal of Environmental Science, Toxicology and Food Technology, vol. 9, no. 11, pp. 38-45, 2015.

[29] R. M. Hesnawi and M. M. Adbeib, "Effect of nutrient source on indigenous biodegradation of diesel fuel contaminated soil," APCBEE Procedia, vol. 5, pp. 557-561, 2013.

[30] H. S. Yap, N. N. Zakaria, A. Zulkharnain, S. Sabri, C. GomezFuentes, and S. A. Ahmad, "Bibliometric analysis of hydrocarbon bioremediation in cold regions and a review on enhanced soil bioremediation," Biology, vol. 10, no. 5, p. 354, 2021.

[31] K. M. McFarlin, R. C. Prince, R. Perkins, and M. B. Leigh, "Biodegradation of dispersed oil in arctic seawater at $-1^{\circ} \mathrm{C}$," PLoS One, vol. 9, no. 1, Article ID e84297, 2014.

[32] P. Gkorezis, M. Daghio, A. Franzetti, J. D. Van Hamme, W. Sillen, and J. Vangronsveld, "The interaction between plants and bacteria in the remediation of petroleum hydrocarbons: an environmental perspective," Frontiers in Microbiology, vol. 7, Article ID 1836, 2016.

[33] D. K. Chaudhary and J. Kim, "New insights into bioremediation strategies for oil-contaminated soil in cold environments," International Biodeterioration and Biodegradation, vol. 142, pp. 58-72, 2019.

[34] H. Zhang, X. Yuan, T. Xiong, H. Wang, and L. Jiang, "Bioremediation of co-contaminated soil with heavy metals and pesticides: influence factors, mechanisms and evaluation methods," Chemical Engineering Journal, vol. 398, Article ID 125657, 2020.

[35] K. Tao, X. Zhang, X. Chen, X. Liu, X. Hu, and X. Yuan, "Response of soil bacterial community to bioaugmentation with a plant residue-immobilized bacterial consortium for crude oil removal," Chemosphere, vol. 222, pp. 831-838, 2019.

[36] M. F. Ortega, D. E. Guerrero, M. J. García-Martínez et al., "Optimization of landfarming amendments based on soil texture and crude oil concentration," Water, air and Soil Pollution, vol. 30, no. 7, p. 229, 2018.

[37] M.-S. Safdari, H.-R. Kariminia, M. Rahmati et al., "Development of bioreactors for comparative study of natural attenuation, biostimulation, and bioaugmentation of petroleum-hydrocarbon contaminated soil," Journal of Hazardous Materials, vol. 342, pp. 270-278, 2018.

[38] M. Cecotti, B. M. Coppotelli, V. C. Mora, M. Viera, and I. S. Morelli, "Efficiency of surfactant-enhanced bioremediation of aged polycyclic aromatic hydrocarbon-contaminated soil: link with bioavailability and the dynamics of the bacterial community," The Science of the Total Environment, vol. 634, pp. 224-234, 2018.

[39] L. Lu, J. Zhang, and C. Peng, "Shift of soil polycyclic aromatic hydrocarbons (PAHs) dissipation pattern and microbial community composition due to rhamnolipid supplementation," Water, Air, and Soil Pollution, vol. 230, no. $5,2019$.

[40] N. Haleyur, E. Shahsavari, S. S. Jain et al., "Influence of bioaugmentation and biostimulation on PAH degradation in aged contaminated soils: response and dynamics of the bacterial community," Journal of Environmental Management, vol. 238, pp. 49-58, 2019.

[41] M. Woźniak-Karczewska, P. Lisiecki, W. Białas et al., "Effect of bioaugmentation on long-term biodegradation of diesel/ biodiesel blends in soil microcosms," The Science of the Total Environment, vol. 671, pp. 948-958, 2019.

[42] D. C. Wolf and J. Gan, "Influence of rhamnolipid biosurfactant and Brij-35 synthetic surfactant on 14C-Pyrene mineralization in soil," Environmental Pollution, vol. 243, pp. 1846-1853, 2018.

[43] M. Oualha, N. Al-Kaabi, M. Al-Ghouti, and N. Zouari, "Identification and overcome of limitations of weathered oil hydrocarbons bioremediation by an adapted Bacillus sorensis strain," Journal of Environmental Management, vol. 250, Article ID 109455, 2019.

[44] J. Czarny, J. Staninska-Pięta, A. Piotrowska-Cyplik et al., "Assessment of soil potential to natural attenuation and 
autochthonous bioaugmentation using microarray and functional predictions from metagenome profiling," Annals of Microbiology, vol. 69, no. 9, pp. 945-955, 2019.

[45] K. Ramadass, M. Megharaj, K. Venkateswarlu, and R. Naidu, "Bioavailability of weathered hydrocarbons in engine oilcontaminated soil: impact of bioaugmentation mediated by Pseudomonas spp. on bioremediation," The Science of the Total Environment, vol. 636, pp. 968-974, 2018.

[46] A. Roy, A. Dutta, S. Pal et al., "Biostimulation and bioaugmentation of native microbial community accelerated bioremediation of oil refinery sludge," Bioresource Technology, vol. 253, pp. 22-32, 2018.

[47] S. P. Maletić, J. M. Beljin, S. D. Rončević, M. G. Grgić, and B. D. Dalmacija, "State of the art and future challenges for polycyclic aromatic hydrocarbons is sediments: sources, fate, bioavailability and remediation techniques," Journal of Hazardous Materials, vol. 365, pp. 467-482, 2019.

[48] J. E. Kostka, A. P. Teske, S. B. Joye, and I. M. Head, "The metabolic pathways and environmental controls of hydrocarbon biodegradation in marine ecosystems," Frontiers in Microbiology, vol. 5, no. 471, pp. 471-473, 2014.

[49] P. Galitskaya, L. Akhmetzyanova, and S. Selivanovskaya, "Biochar-carrying hydrocarbon decomposers promote degradation during the early stage of bioremediation," Biogeosciences, vol. 13, no. 20, pp. 5739-5752, 2016.

[50] L. Ławniczak, M. Wo'zniak-Karczewska, A. P. Loibner, H. J. Heipieper, and L. Chrzanowski, Molecules, vol. 25, no. 856, pp. 1-19, 2020.

[51] G. O. Adams, I. Ehinomen, P. T. Fufeyin, and S. E. Okoro, "Bioremediation, biostimulation and bioaugmention: a review," International Journal of Environmental Bioremediation and Biodegradation, vol. 3, no. 1, pp. 28-39, 2015.

[52] E. Dindar, F. Olcay, H. S. Başkaya, and T. Şağban, "Biodegradation of used engine oil in a wastewater sludgeamended agricultural soil," Turkish Journal of Agriculture and Forestry, vol. 40, pp. 631-641, 2016.

[53] I. Zawierucha, G. Malina, W. Ciesielski, and P. Rychter, "Effectiveness of intrinsic biodegradation enhancement in oil hydrocarbons contaminated soil," Archives of Environmental Protection, vol. 40, no. 1, pp. 101-113, 2014.

[54] S. Sonawdekar, "Bioremediation: a boon to hydrocarbon degradation," International Journal of Environmental Sciences, vol. 2, no. 4, pp. 2408-2424, 2012.

[55] M. Abdulrasheed, N. N. Zakaria, A. F. Ahmad Roslee et al., "Biodegradation of diesel oil by cold-adapted bacterial strains of Arthrobacter spp. from Antarctica," Antarctic Science, vol. 32, no. 5, pp. 341-353, 2020.

[56] S. Sihag, H. Pathak, and D. P. Jaroli, "Factors affecting the rate of biodegradation of polyaromatic hydrocarbons," International Journal of Pure and Applied Bioscience, vol. 2, no. 3, pp. 185-202, 2014.

[57] N. Das and P. Chandran, "Microbial degradation of petroleum hydrocarbon contaminants: an overview," Biotechnology Research International, vol. 2011, pp. 1-13, 2011.

[58] Y. Teng and W. Chen, "Soil microbiomes-a promising strategy for contaminated soil remediation: a review," Pedosphere, vol. 29, no. 3, pp. 283-297, 2019.

[59] B. M. Macaulay, "Understanding the behavior of oil degrading microorganisms to enhance the microbial remediation of spilled Petroleum," Applied Ecology and Environmental Research, vol. 13, no. 1, pp. 247-262, 2014.

[60] R. Omrani, G. Spini, E. Puglisi, and D. Saidane, "Modulation of microbial consortia enriched from different polluted environments during petroleum biodegradation," Biodegradation, vol. 29, no. 2, pp. 187-209, 2018.

[61] D. Maliji, Z. Olama, and H. Holail, "Environmental studies on the microbial degradation of oil hydrocarbons and its application in Lebanese oil polluted coastal and marine ecosystem," International Journal of Current Microbiology and Applied Sciences, vol. 2, no. 6, pp. 1-18, 2013.

[62] J. Liu, H. P. Bacosa, and Z. Liu, "Potential environmental factors affecting oil-degrading bacterial populations in deep and surface waters of the Northern Gulf of Mexico," Frontiers in Microbiology, vol. 7, p. 2131, 2017.

[63] M. Wu, X. Ye, K. Chen, W. Li, J. Yuan, and X. Jiang, "Bacterial community shift and hydrocarbon transformation during bioremediation of short-term petroleum-contaminated soil," Environmental Pollution, vol. 223, pp. 657-664, 2017.

[64] M. Wu, W. A. Dick, W. Li et al., "Bioaugmentation and biostimulation of hydrocarbon degradation and the microbial community in a petroleum-contaminated soil," International Biodeterioration and Biodegradation, vol. 107, pp. 158-164, 2016.

[65] A. Hamzah, V. Manikan, and N. A. F. Abd Aziz, "Biodegration of tapis crude oil using consortium of bacteria and fungi: optimization of crude oil concentration and duration of incubation by response surface methodology," Sains Malaysiana, vol. 46, no. 1, pp. 43-50, 2017.

[66] E. Moliterni, R. G. Jiménez-Tusset, M. Villar Rayo, L. Rodriguez, F. J. Fernández, and J. Villaseñor, "Kinetics of biodegradation of diesel fuel by enriched microbial consortia from polluted soils," International journal of Environmental Science and Technology, vol. 9, no. 4, pp. 749-758, 2012.

[67] M. Chen, P. Xu, G. Zeng, C. Yang, D. Huang, and J. Zhang, "Bioremediation of soils contaminated with polycyclic aromatic hydrocarbons, petroleum, pesticides, chlorophenols and heavy metals by composting: applications, microbes and future research needs," Biotechnology Advances, vol. 33, no. 6, pp. 745-755, 2015.

[68] T. F. Ferreira, M. A. Z. Coelho, and M. H. M. d. Rocha-Leão, "Factors influencing crude oil biodegradation by Yarrowia Lipolytica," Brazilian Archives of Biology and Technology, vol. 55, no. 5, pp. 785-791, 2012.

[69] L. F. Martins and R. S. Peixoto, "Biodegradation of petroleum hydrocarbons in hypersaline Environments," Brazilian Journal of Microbiology, vol. 865872 pages, 2012.

[70] H. Rhbal, S. Souabi, M. Safi et al., "Soils bioremediation of hydrocarbons and green waste elimination through composting process," International Journal of Environmental Monitoring and Analysis, vol. 2, no. 6, pp. 13-22, 2014.

[71] M. Shahriari Moghadam, G. Ebrahimipour, B Abtahi, A Ghassempour, and M. S. Hashtroudi, "Biodegradation of polycyclic aromatic hydrocarbons by a bacterial consortium enriched from mangrove sediments," Journal of Environmental Health Science and Engineering, vol. 12, no. 114, pp. 1-9, 2014.

[72] S. Varjani, A. Pandey, and V. N. Upasani, "Oilfield waste treatment using novel hydrocarbon utilizing bacterial consortium - a microcosm approach," The Science of the Total Environment, vol. 745, pp. 141043-141047, 2020.

[73] S. Geng, W. Cao, J. Yuan et al., "Microbial diversity and cooccurrence patterns in deep soils contaminated by polycyclic aromatic hydrocarbons (PAHs)," Ecotoxicology and Environmental Safety, vol. 203, Article ID 110931, 2020.

[74] M. Omarova, L. T. Swientoniewski, I. K. Mkam Tsengam et al., "Biofilm formation by hydrocarbon-degrading marine 
bacteria and its effects on oil dispersion," ACS Sustainable Chemistry and Engineering, vol. 7, no. 17, pp. 14490-14499, 2019.

[75] M. Perera, D. Wijayarathna, S. Wijesundera, M. Chinthaka, G. Seneviratne, and S. Jayasena, "Biofilm mediated synergistic degradation of hexadecane by a naturally formed community comprising Aspergillus flavus complex and $\mathrm{Ba}$ cillus cereus group," BMC Microbiology, vol. 19, no. 84, pp. 84-89, 2019.

[76] D. Dasgupta, R. Ghosh, and T. K. Sengupta, "Biofilm-mediated enhanced crude oil degradation by newly isolated pseudomonas species," ISRN Biotechnology, vol. 2013, Article ID 250749, 13 pages, 2012.

[77] A. Meliani and A. Bensoltane, "Enhancement of hydrocarbons degradation by use of Pseudomonas biosurfactants and biofilms," Journal of Petroleum \& Environmental Biotechnology, vol. 5, no. 1, pp. 1-7, 2014.

[78] A. I. Okoh, "Biodegradation alternative in the cleanup of petroleum hydrocarbon pollutants," Biotechnology and Molecular Biology Reviews, vol. 1, no. 2, pp. 38-50, 2006.

[79] X.-Y. Lu, T. Zhang, and H. H.-P. Fang, "Bacteria-mediated PAH degradation in soil and sediment," Applied Microbiology and Biotechnology, vol. 89, no. 5, pp. 1357-1371, 2011.

[80] S. J. Varjani, "Microbial degradation of petroleum hydrocarbons," Bioresource Technology, vol. 223, pp. 277-286, 2017.

[81] J. L. Stroud, G. I. Paton, and K. T. Semple, "Microbe-aliphatic hydrocarbon interactions in soil: implications for biodegradation and bioremediation," Journal of Applied Microbiology, vol. 102, no. 5, pp. 1239-1253, 2007.

[82] R. Bajagain, P. Gautam, and S.-W. Jeong, "Degradation of petroleum hydrocarbons in unsaturated soil and effects on subsequent biodegradation by potassium permanganate," Environmental Geochemistry and Health, vol. 42, no. 6, pp. 1705-1714, 2020.

[83] S. A. B. Weelink, M. H. A. van Eekert, and A. J. M. Stams, "Degradation of BTEX by anaerobic bacteria: physiology and application," Reviews in Environmental Science and Biotechnology, vol. 9, no. 4, pp. 359-385, 2010.

[84] A. Dell'Anno, F. Beolchini, M. Gabellini, L. Rocchetti, A. Pusceddu, and R. Danovaro, "Bioremediation of petroleum hydrocarbons in anoxic marine sediments: consequences on the speciation of heavy metals," Marine Pollution Bulletin, vol. 58, no. 12, pp. 1808-1814, 2009.

[85] R. U. Meckenstock, M. Elsner, C. Griebler et al., "Biodegradation: updating the concepts of control for microbial cleanup in contaminated aquifers," Environmental Science and Technology, vol. 49, no. 12, pp. 7073-7081, 2015.

[86] L. Chun-Hua, W. Yuk-Shan, and F. T. Nora, "Anaerobic biodegradation of polycyclic aromatic hydrocarbons with amendment of iron (III) in mangrove sediment slurry," Bioresource Technology, vol. 101, no. 21, pp. 8083-8092, 2010.

[87] I. C. Ossai, A. Ahmed, A. Hassan, and F. S. Hamid, "Remediation of soil and water contaminated with petroleum hydrocarbon: a review," Environmental Technology and Innovation, vol. 17, pp. 1-42, 2020.

[88] K. Mulugeta, M. Kamaraj, M. Tafesse, and J. Aravind, “A review on production, properties, and applications of microbial surfactants as a promising biomolecule for environmental applications," Strategies and Tools for Pollutant Mitigation, Springer, Cham, Switzerland, pp. 3-28, 2021.

[89] L. N. Ukiwe, U. U. Egereonu, P. C. Njoku, C. I. A. Nwoko, and J. I. Allinor, "Polycyclic aromatic hydrocarbons degradation techniques," International Journal of Chemistry, vol. 5, no. 4, pp. 43-55, 2013.

[90] A. Mrozik, Z. Piotrowska-Seget, and S. Labuzek, "Bacterial degradation and bioremediation of polycyclic aromatic hydrocarbons," Polish Journal of Environmental Studies, vol. 12, no. 1, pp. 15-25, 2003.

[91] L. M. Martínez Á, L. A. M. Ruberto, J. M. Gurevich, and W. P. Mac Cormack, "Environmental factors affecting reproducibility of bioremediation field assays in Antarctica," Cold Regions Science and Technology, vol. 169, pp. 1-9, 2019.

[92] V. M. Ibeanusi, "Putting microbes to work on subsurface contamination," Journal of Bioremediation and Biodegradation, vol. 3, no. 5, 2012.

[93] K. L. Njoku, M. O. Akinola, and B. O. Oboh, "Phytoremediation of crude oil polluted soil: effect of cow dung augmentation on the remediation of crude oil polluted soil by glycine max," Research Journal of Applied Sciences, vol. 8, no. 1, pp. 277-282, 2012.

[94] J. C. Okolo, E. N. Amadi, and C. T. I. Odu, "Effects of soil treatments containing poultry manure on crude oil degradation in a sandy loam soil," Applied Ecology and Environmental Research, vol. 3, no. 1, pp. 47-53, 2005.

[95] R. H. Adams, K. Kanga-Leyva, F. J. Guzmán-Osorio, and E. E. Espinosa, "Comparison of moisture management methods for the bioremediation of hydrocarbon contaminated soil," African Journal of Biotechnology, vol. 10, no. 3, pp. 394-404, 2011.

[96] M. H. Børresen and A. G. Rike, "Effects of nutrient content, moisture content and salinity on mineralization of hexadecane in an Arctic soil," Cold Regions Science and Technology, vol. 48, no. 2, pp. 129-138, 2007.

[97] M. F. Imron, S. B. Kurniawan, N. I. Ismail, and S. R. S. Abdullah, "Future challenges in diesel biodegradation by bacteria isolates: a review," Journal of Cleaner Production, vol. 251, pp. 1-18, 2020.

[98] K. Singh and S. Chandra, "Treatment of petroleum hydrocarbon polluted environment through bioremediation: Review," Pakistan Journal of Biological Sciences, vol. 17, no. 1, pp. 1-8, 2014.

[99] R. M. Pawar, "The effect of soil pH on bioremediation of polycyclic aromatic hydrocarbons (PAHS)," Journal of Bioremediation and Biodegradation, vol. 6, p. 291, 2015.

[100] C. Zhong, C. L. Nesbø, G. G. Goss, B. D. Lanoil, and D. S. Alessi, "Response of aquatic microbial communities and bioindicator modelling of hydraulic fracturing flowback and produced water," FEMS Microbiology Ecology, vol. 1, no. 5 , p. $96,2020$. 